\title{
Revolutionizing Bantu Lexicography - A Zulu Case Study
}

Gilles-Maurice de Schryver, Department of African Languages and Cultures, Ghent University, Belgium; Xhosa Department, University of the Western Cape, Bellville, South Africa; and TshwaneDJe HLT, Stellenbosch, South Africa (gillesmaurice.deschryver@UGent.be)

\begin{abstract}
Zulu uses a conjunctive writing system, that is, a system whereby relatively short linguistic words are joined together to form long orthographic words with complex morphological structures. This has led to the so-called 'stem tradition' in dictionary making — for Zulu, as well as for most other Bantu languages. Given this lemmatization approach has been found to be inadequate for young learners (who fail to isolate stems), the development of a new approach was imperative for them, but until recently deemed impossible to implement. In this paper it is argued that it is now perfectly possible to reverse the unproductive trend, and to opt for the lemmatization of full words for all but one of the word classes in Bantu. This revolution is made possible thanks to the recent availability of relatively large corpora, with which the really frequent citation options may be pinpointed. Rather than a mission statement, this paper offers the result for all word classes. To do so, an actual guide to the use of a Zulu dictionary is re-represented and annotated.
\end{abstract}

Keywords: ZULU, BANTU, DICTIONARY, USAGE GUIDE, MINI-GRAMMAR, WORD CLASSES, STEM VS. WORD LEMMATIZATION, CORPUS, USER-FRIENDLY

Samenvatting: Bantoe lexicografie radicaal omgooien - een gevalsanalyse voor Zoeloe. Zoeloe maakt gebruik van een conjunctief schrijfsysteem, d.w.z. een systeem waarbij relatief korte linguïstische woorden vast aan elkaar geschreven worden met lange orthografische woorden tot gevolg, die ook nog complexe morfologische structuren vertonen. Dit heeft geleid tot wat men de 'stam traditie' in de lexicografie is gaan noemen — voor Zoeloe, alsook voor de meeste andere Bantoetalen. Aangezien deze lemmatisatieaanpak ongeschikt is gebleken voor jonge gebruikers (die woordstammen maar niet kunnen isoleren), moest voor hen een nieuwe aanpak ontwikkeld worden. Tot voor kort werd zo'n aanpak echter als niet-implementeerbaar beschouwd. In dit artikel wordt geargumenteerd dat het vandaag de dag perfect mogelijk is om de onproductieve trend om te keren, en om te kiezen voor het lemmatiseren van volledige woorden voor alle woordklassen op één na in Bantoe. Deze radicale ommezwaai werd mogelijk gemaakt dankzij het recent beschikbaar komen van relatief grote corpora, waarmee de echt frequente opties qua trefwoordkeuzes bepaald kunnen worden. In de plaats van louter de beschrijving van een doelstelling, biedt dit artikel oplossingen voor alle woordklassen. Daartoe wordt de effectieve gebruikersgids van een Zoeloe woordenboek voorgesteld en van commentaar voorzien.

Sleutelwoorden: ZOELOE, BANTOE, WOORDENBOEK, GEBRUIKERSGIDS, MINIGRAMMATICA, WOORDKLASSEN, STAM- VS. WOORD-LEMMATISATIE, CORPUS, GEBRUIKSVRIENDELIJK 


\section{The one-size-fits-all problem}

Although dictionaries for the Bantu languages have been compiled for several centuries now, and although Bantu metalexicography is at least 150 years old (cf. Benson 1964), the field has been plagued throughout by what one could call the one-size-fits-all approach. By and large that 'size' has been to attempt to lemmatize all words from all word classes under their stems, no matter the target user envisaged. Arguably, from a strict morphological point of view, this is a perfectly valid and linguistically sound approach. Students at institutes of higher learning are confronted with it from day one of their studies, and end up mastering the system given their otherwise general grounding in linguistics and their year-long exposure to a dictionary culture in a variety of languages. Such students are typically non-Africans studying at universities in the West or East. When that same approach is used to compile dictionaries for elementary learners, who moreover have not had the chance to be exposed to any other dictionaries in their lives, the dictionaries have shown to be too challenging to use. Here the intended user is typically a mother-tongue speaker of a Bantu language, in need of a dictionary with local relevance.

The problem of the one-size-fits-all approach for Bantu lexicography has been noted before in the scientific literature, and it is often presented as a need to choose between stem lemmatization (more often than not seen as 'the right size') vs. word lemmatization (typically 'the wrong size', or at least looked down upon, especially by linguists). Half a century ago Benson, after surveying the field, concluded in favour of stem lemmatization as follows:

It is now right and proper to [...] make certain suggestions which could help future compilers of dictionaries of African languages, whoever they may be, to avoid some of the more obvious pitfalls. [...] there are no rules laid down for lexicographers, and whatever has been learnt by toil and sweat, by trial and error, is worth passing on. [...] One cardinal principle which emerges from our study is that everything which needs to be said about a stem or root should be channelled into one single full article, complete with citations if needed.

— Benson (1964: 78, 80, 82)

Merely a year later, however, in a discussion of a Luganda-English dictionary, Snoxall argued in favour of word lemmatization, as follows:

[E]ven many Baganda would have little idea under what root form they should look up many of the commonest words which they use. [...] The general principle of entering words in a dictionary under roots [...] could never be of great assistance [...] It would seem therefore that, although disappointing perhaps to etymologists, a decision to enter headwords in the form in which they are used in actual speech, as words possessing meaning, [...] will be welcomed by the great majority of the users of the dictionary.

- Snoxall (1965: 27-28) 
The debate has raged on ever since, with Bennett writing two decades later:

There has been debate as to the proper arrangement of the Bantu lexicon, and the question is far from settled. The inflection of nominals and verbals by means of prefixes, and the complex and productive derivational system, both characteristic of Bantu languages, pose difficulties [...] If items are alphabetized by prefix [...] a verb will be listed far from its nominal derivations, however transparent these may be. [...] A competing school arranges the lexicon by stem or root; this usefully groups related items, and saves on cross-referencing. Unfortunately, in such a system the user must be able to identify the stem, which given the sometimes complex morphophonemics of Bantu languages may not be easy.

— Bennett (1986: 3-4)

A more recent and excellent overview of the various pros and cons of the two opposing approaches can be found in Van Wyk (1995). The opposition, however, is a false opposition, as no Bantu dictionaries exist that are purely stembased, neither do Bantu dictionaries exist that are purely word-based. I have pointed this out in an earlier contribution, one in which I had proposed a 'new approach':

These two extremes are but two poles on a continuum, of course. In reality, a 'traditional' stem-based approach to lemmatization [...] also has word features, and thus moves up on the continuum, while the approach advocated in this research article moves in the other direction of the continuum, away from the sole orthographic word. [The figure below] summarizes this situation, where the shaded triangle illustrates the increase in user-friendliness for junior users as one moves from stem-like to word-like lemmatization. With experience, however, one tends to crave for more condensed and more abstract information, and thus the wish to move in the other direction.

— De Schryver (2008a: 86-87)

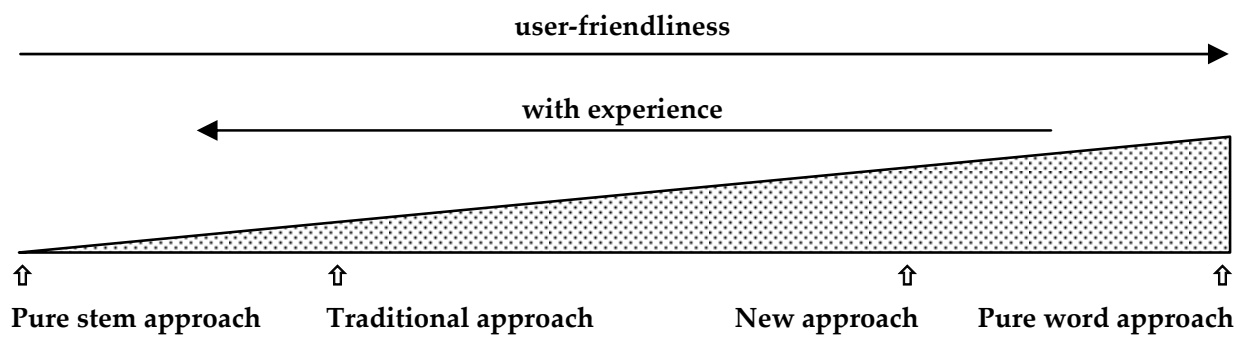

It is my contention that the great majority of the existing dictionaries for the Bantu languages are actually variations of the 'traditional approach' depicted on the continuum, thus at heart dictionaries in which the lexicon is grouped around stems, with some dictionaries showing word-like features for selected word classes only, at which point they move up the continuum a little. Moving towards the word approach is easier to achieve for some Bantu languages than it is for others, depending on the degree of conjunctivism / disjunctivism of the 
Bantu language in question (cf. Prinsloo and De Schryver 2002). Actually, no more than a handful of Bantu lexicographers have consciously tried to approach the continuum from the other (word) pole for all word classes. Moreover, and as we will see below, achieving this goal for the highly conjunctive Bantu languages has only become possible in recent years, thanks to the availability of (relatively) large corpora, from which real facts can be derived, rather than confining lexicographers to theoretical conjectures.

New types of dictionaries for the Bantu languages have indeed started to be compiled - that is, dictionaries for mother-tongue speakers, who do not have any previous exposure to a dictionary culture. Interestingly, the pressing need for such dictionaries was not only felt near-simultaneously in both monolingual and bilingual environments, the compilation of new, word-based dictionaries also started around the same time. For example, in Uganda, M. Nabirye undertook to compile the first monolingual dictionary for Lusoga, and in doing so she placed the (non-existent!) reference skills of the two million Basoga first. Her extensive research (Nabirye 2008) quite naturally led her to compile a dictionary in which words are listed, the only 'natural' language units according to the mother-tongue speakers she tested her dictionary material on (cf. Nabirye 2009a, 2009b). The result — the Eiwanika ly'Olusoga (Nabirye 2009) is a most-powerful statement by a native speaker of a Bantu language.

Meanwhile in South Africa, several teams led by myself - a non-mothertongue speaker of the Bantu languages — began work on a series of bilingual dictionaries with in each case one of the official South African Bantu languages and English as treated language pairs. The overarching theoretical framework was described in my PhD thesis (De Schryver 2004), and to date two dictionaries - the Oxford Bilingual School Dictionary: Northern Sotho and English (De Schryver 2007), and the Oxford Bilingual School Dictionary: Zulu and English (De Schryver 2010) - have been completed and published. An accompanying workbook was also prepared for the Northern Sotho dictionary (Taljard et al. 2008), ${ }^{1}$ and both dictionaries have received favourable academic reviews; see for instance Prinsloo (2009) for the Northern Sotho dictionary, and Prinsloo (2010) for the Zulu dictionary.

Compared to any other earlier dictionaries for the Bantu languages at large, the Oxford Bilingual School Dictionary: Zulu and English (henceforth OZSD) is the first dictionary for a Bantu language to radically move away from the one-size-fits-all approach to lemmatization, in that the reference skills of the envisaged target user group forced me to come up with a new, tailored, wordbased approach. In the present paper this approach is briefly introduced.

\section{A daunting finding}

Although the new approach is a direct implementation of the proposals which I formulated in my PhD thesis (completed in 2004), it would not have been possible to subsequently release two dictionaries at three-year intervals (for North- 
ern Sotho in 2007, and for Zulu in 2010) without the support of large dictionary teams. ${ }^{2}$ At this point I would like to salute and thank them, as without them my proposals would have remained academic theorizing; with them my dreams became a reality. For anyone wishing to make analogous dictionaries, it is instructive to have an idea about some of the practical aspects of these dictionary projects. I will use the OZSD as a case in point.

The OZSD is a bidirectional, bilingual school dictionary with Zulu and English as treated language pair, for use in South African schools in Grades 4 to 9 (i.e. the intermediate and senior phase of GET), ${ }^{3}$ covering 5000 lemmas on each side. The OZSD has been designed to help students read and write Zulu better, if they are learners of Zulu, or read and write English better, if they are learners of English. The fact that it is a school dictionary had far-reaching implications for its design. Chief among those is that, in addition to the two Ato-Z sections, which amount to a total of 582 pages, the OZSD contains extensive extra-matter texts, totalling 58 pages (or ten percent of the A-to-Z sections), the main purpose of which is to teach a full-experience dictionary culture. ${ }^{4}$ Where relevant, those extra-matter pages are presented in both Zulu and English. As such, the front matter has a section on 'Dictionary features', in which the structure of the dictionary articles is visualised, and a gentle 'Introduction' on why dictionaries are important, on how the OZSD (a corpus-driven dictionary) differs from other dictionaries, and on what can be found in it. Completing the 12 pages of the front matter are also the title and imprint page, and a table of contents.

The middle matter or 'Study section', placed between the Zulu to English and English to Zulu sides of the dictionary, opens with 'Dictionary activities' in Zulu and English, taking the learners all the way from the sequence of the alphabet to both decoding and encoding exercises with the dictionary. Writing skills are covered in samples of e-mails, letters and electronic (SMS) messages. For Zulu, a mini-grammar and information on pronunciation are included, and for English, irregular verbs, punctuation and spelling are covered. All these sections, together with a detailed table of contents, amount to 30 pages.

The back matter has been conceived as a 'Reference section', and opens with six full-page plates with illustrations (domestic, wild and sea animals; small creatures; fruit and vegetables; etc.), and further contains information on the South African provinces, languages and phases of education, as well as numerous tables that bring together closed-class items (months, days, seasons; the solar system; public holidays; symbols; etc.), the numbering system in Zulu, and weights and measurements. Together with a detailed table of contents, as well as a page with the answers to the dictionary exercises from the middle matter, this back matter contains 16 pages.

Coordinating all these different components of the OZSD is no small matter, and considerable pressure was put on the human as well as financial resources - there never seemed to be enough of either of them. Although a tiny pilot was run in 2005 already (cf. De Schryver 2006), and although a preliminary draft of the Zulu to English side had been compiled by 2006, it is only 
with a third team that the finish line was reached. In addition to myself as the editor-in-chief, the final dictionary development team consisted of a chief compiler (Nomusa Sibiya) and a linguist (Arnett Wilkes), six more compilers (Sibusiso Dlamini, Thandeka Cebekhulu, Wo Mthembu, Mduduzi Ndlovu, Moses Biyela, Kholiswa Sitole), two proofreaders for Zulu (Msawakhe Hlengwa, Thokozani Buthelezi), two proofreaders for English (John Linnegar, Celia Slater), a consultant on curriculum entries (Daphne Paizee), and two computational engineers (David Joffe, Malcolm MacLeod). At the publishing house, a publishing manager (Megan Hall), two project managers (Fred Pheiffer, Phillip Louw), an editorial assistant (Lorna Hiles), three designers (Peter Burgess: A-to-Z, Oswald Kurten: extra matter, Sharna Sammy: cover), and two illustrators (Julien Marais, Leigh-Anne Wolfaardt) supported and interacted with the dictionary development team. Finally, two typesetters (Tommy Bell: A-to-Z, Ingrid Richards: extra matter) took care of the final layout. That's a total of 27 people to prepare the manuscript!

I have chosen to list all these team members here, rather than hidden in an endnote, as I want to make sure that it is clear from the start that everything possible was done to ensure that all the best available skills were brought together to create the OZSD. While the team at the publishing house was largely responsible for the development of an English dictionary-template for the English to Zulu side, to be translated into Zulu and coordinated with the material on the Zulu to English side by the dictionary development team, the main task of the dictionary development team itself was the creation of the Zulu to English side from scratch. To do so, that team had a relatively large Zulu corpus at their disposal, with which the Zulu lemma list could first be drawn up, and then queried for each and every lemma. The various meanings for each lemma were mapped directly onto the uses as seen in the corpus, and each main meaning was illustrated with material taken straight from the corpus.

All of this, of course, is easier said (or 'recounted' here) than done, and to do justice to all the details of the processes followed in compiling the OZSD, one would need far more pages than those that are available in a single scientific paper. There is firstly a big difference between the ways in which the two A-to-Z sides of the dictionary were compiled, an aspect with implications for the (non-)reversibility of the dictionary. That would have to be explained in a paper. Detailing how the Zulu lemma list was created would need at least one other paper-length treatment. A further paper could then deal with the description of the overall macrostructural as well as microstructural decisions. More detailed studies for the English side would have to focus on the presentation of the Zulu lexicon in the microstructure, as one can assume that general lemmatization decisions need not be covered for English. Grouping certain word classes or parts of speech (POSs), this could be done in about five papers. Detailing the lemmatization decisions as well as the dictionary structure on the Zulu side, however, can only be done in earnest if each and every word class is considered in isolation first, with generalizations in a second phase. There are 
21 main Zulu word classes in the OZSD, and 42 if one includes the sub-word classes. Attention should furthermore also go to all the extra matter texts, conceived as front, middle and back matter in the OZSD. Together, I reckon about ten papers would be needed for a proper coverage of the various extra matter features. In short, then, giving a full account of the many aspects revolving around the creation of a dictionary such as the OZSD would require anything between 40 to 60 scientific papers. At about 20 pages each, this amounts to 800 to 1200 pages in total, the equivalent of three full-length monographs!

This is a daunting finding, and one that has worried me for some years now. It is all good and well to write overview papers, in which one briefly sketches the general approach (cf. e.g. De Schryver 2008), but if one also wishes to stimulate a healthy academic debate, then more detailed studies are required, studies in which each step of one's reasoning is carefully argued. Specifically for the OZSD, I have presented detailed accounts for four Zulu word classes to date: possessive pronouns (De Schryver and Wilkes 2008), adjectives (De Schryver 2008a), quantitative pronouns (De Schryver 2008b), and ideophones (De Schryver 2009). Rather than to continue with the series of Zulu word classes, which at the current rate will take at least another decade, and rather than to give yet another overview (this time for Zulu, rather than for Cilubà, Swahili and Northern Sotho, as in De Schryver 2008), I have opted for a compromise in this paper. The OZSD itself actually contains a text that is particularly fit for this purpose, and this text is presented next.

\section{How to use your dictionary (a Zulu mini-grammar)}

On pages S13 to S26 of the Study section, thus right in the middle of the dictionary, the OZSD contains a chapter titled 'How to use your dictionary (a Zulu mini-grammar)', which is both a mini-grammar of Zulu in disguise and a true guide to the proper use of the Zulu dictionary. In the fourteen sub-sections that follow, I will present the text of that chapter in full, and I will intersperse it with additional comments. In doing so I hope to achieve at least four goals. Firstly, by presenting the full text of one of the extended extra-matter texts of a published dictionary, I illustrate the features of an actual text in action, rather than a proposal which may or may not materialize. Secondly, by using this particular text, I will automatically cover a full system, and run through all parts of speech of a language, thus covering the breadth one expects to find in overview papers. Thirdly, in the process the reader will have been offered a synoptic view of the grammar of Zulu relevant for lexicographic purposes, an aspect especially welcome to those not familiar with this Bantu language. And fourthly, with the added comments this paper functions as a stand-alone text, in which just enough depth is presented to serve as a launching pad for further academic discussions.

This approach remains an experiment, however, as two writing styles will now alternate throughout Section 3. On the one hand a dictionary user is 
addressed, who is a Grade 4 to 9 learner, and for whom everything that is said is assumed to be new. I address that user directly, and avoid, wherever possible, all unnecessary 'difficult words'. On the other hand I am addressing the reader of the present paper, in an academic register, for whom using the correct terminology is crucially important, and for whom enough context and references must frame the work. The presentation starts with the text as found in the OZSD, and the added material is flagged with numbered comment fields in a smaller font size. ${ }^{5}$

\subsection{Introduction}

In this dictionary English words (in the English to Zulu side) have been listed as in any other English dictionary. If you are uncertain how to use a dictionary and would like some practice, please work through the 'Dictionary activities' first (see pages $\mathrm{S} 4$ to $\mathrm{S6}$ ).

Comments 1: From the start a clear division is made between looking up lemmas in the English side vs. looking up lemmas in the Zulu side of the OZSD. The 'Dictionary activities' the user is referred to have also been prepared in Zulu (to be found on pages S2 to S4). Note the use of the terms 'word' and 'listed' rather than 'lemma' and 'lemmatized'. Following these two opening sentences, the remainder of the mini-grammar deals exclusively with the lemmatization and treatment of the Zulu lexicon, as seen below.

Zulu words (in the Zulu to English side) have been listed in a radically new way, unlike the approach used in any other dictionary for Zulu. In this dictionary you can look up many Zulu words directly as they are written and used. This is different to conventional Zulu dictionaries, where you need to break down most words until you reach the roots or stems of the words - and it is the roots or stems which have been listed in those dictionaries. In contrast, in this dictionary all primary prefixes are still attached to the word roots and stems, except in the case of verbs. For verbs you will still need to learn to cut off all verbal prefixes, as well as some other formatives. Therefore, studying and knowing Zulu grammar remains very important. You can only use this Zulu dictionary with success if you use it together with your Zulu textbook. What we have done in this dictionary is to make it much easier for you to find the words you need.

Comments 2: This section introduces the main revolutionary aspect of the OZSD, viz. the fact that for all Zulu word classes except one, an orthographic word was chosen as lemma rather than a root or stem. ${ }^{6}$ No information is given in the Zulu mini-grammar as to how words were chosen, but the use of a corpus is mentioned in the Introduction which is found in the front matter of the dictionary. The OZSD is not the place to explain this, nor is the present paper (as a paper each is needed per word class, cf. the penultimate paragraph of Section 2 above). What the Zulu mini-grammar does do is to explain the result for each word class. I can add here that for each word class as a whole, overall corpus frequencies were used in deciding where to cut off the various morphemes for that word class, so as to arrive at the most frequent type of orthographic form to be used as dictionary citation form for the entire paradigm. Making informed decisions to achieve this would 
not have been possible without the availability of a relatively large Zulu corpus, consisting of a 7.5million-word general-language component and a 1-million-word customised component of school textbooks. ${ }^{7}$ Throughout the scientific literature (cf. e.g. the references to earlier work in Van Wyk 1995), lemmatizing a conjunctively-written language such as Zulu as words rather than stems, has even been considered a theoretical impossibility due to the multiplication effect. With enough evidence of real use, however, and especially with frequency distributions for all words in all word classes - with which one is able to separate the wheat from the chaff, or thus the truly common (and frequent) from the rare (and infrequent) - it becomes possible to select exactly those (frequent) Zulu words that ought to feature in a dictionary aimed at junior learners, rather than having to resort to lemmatizing roots and stems only, for which only generic meanings rather than customised meanings and customised examples can be provided. The prime word class for which the word vs. stem debate has raged is that of the nouns, but it is as relevant for nearly all other word classes as well (adjectives, relatives, (derived) adverbs, pronouns, etc.). Not having the space for further elaborations here, I would like to refer the reader to De Schryver (2008a), where, as a case study for one of the word classes traditionally lemmatized as stems only, the treatment of adjectives as words is presented. For the overall procedure to arrive at the corpus-driven selection of all 5000 Zulu lemmas, see especially page 69 therein.

Not surprisingly, 'the most frequent type of orthographic form' for a particular word class often corresponds with what is intuitively 'the most logical', with the outcome that each resulting lemma is also felt to be 'the most natural word'. As straightforward as this may seem, there were still numerous additional decisions that had to be taken, and many ad-hoc solutions had to be designed due to the fact that language is not as regular as linguists would like it (or force it) to be. As a result, the Zulu lemma list is not only unique in that it presents words rather than stems, but it is also unique to this very dictionary, as it is unlikely that another team of compilers for a Zulu dictionary would arrive at the very same corpus-driven lemmatized frequency list. The dictionary development team felt so strongly about this particular selection of lemmas that a copyright was taken on it, as seen on the imprint page: "๑ Zulu text, including Zulu headword list, TshwaneDJe HLT 2010". ${ }^{8}$ Claiming a copyright on the lexicon of a language is of course ludicrous, but claiming a copyright on a tailored lemma-sign list is not.

Also note the insistence here (and repeated further down) on the fact that the OZSD and the mini-grammar itself need to be used in conjunction with the learners' Zulu textbooks. This should not be seen as a cop-out for the aspects not covered in the mini-grammar, but rather as admitting that a mini-grammar is just that: a brief overview in which one simply cannot treat everything. ${ }^{9}$

Here is an easy example of how to look up words in this dictionary. All the words in the following sentence Phuza amanzi ngazo zonke izikhathi, ikakhulu uma kushisa 'Drink water at all times, especially when it is hot' are shown below. For each word you need to look up, we have shown the word class and a translation:

\begin{tabular}{|c|c|c|c|c|c|c|c|}
\hline $\begin{array}{l}\text { word in sentence: } \\
\text { entry in dictionary: } \\
\text { word class + class no.: } \\
\text { translation: }\end{array}$ & $\begin{array}{l}\text { phuza } \\
\text {-phuza } \\
\text { verb } \\
\text { drink }\end{array}$ & \multicolumn{2}{|c|}{$\begin{array}{l}\operatorname{amanzi} \\
\text { amanzi } \\
\text { noun } 6 \\
\text { water }\end{array}$} & \multicolumn{2}{|c|}{$\begin{array}{l}\text { ngazo } \\
\text { ngazo } \\
\text { temp. adv. } 8 \\
\text { at }\end{array}$} & $\begin{array}{l}\text { zonke } \\
\text { zonke } \\
\text { incl. q. pron. } 8 \\
\text { all }\end{array}$ & $\begin{array}{l}\text { izikhathi } \\
\text { izikhathi > isikhathi } \\
\text { pl. noun } 7 / 8 \\
\text { times }\end{array}$ \\
\hline $\begin{array}{l}\text { word in sentence: } \\
\text { entry in dictionary: } \\
\text { word class + extension: } \\
\text { translation: }\end{array}$ & \multicolumn{2}{|c|}{$\begin{array}{l}\text { ikakhulu } \\
\text { ikakhulu } \\
\text { conjunction } \\
\text { especially }\end{array}$} & \multicolumn{2}{|c|}{$\begin{array}{l}\text { uma } \\
\text { uma } \\
\text { conjunction } \\
\text { when }\end{array}$} & \multicolumn{2}{|c|}{$\begin{array}{l}\text { ku- } \\
\text { [not in dictionary] } \\
\text { indefinite concord } \\
\text { it }\end{array}$} & $\begin{array}{l}\text {-shisa } \\
\text {-shisa } \\
\text { verb + causative } \\
\text { be hot }\end{array}$ \\
\hline
\end{tabular}


As you can see, most of the words in this sentence can be found in the dictionary exactly as they appear in the sentence. The main exception is verbs, which need to be looked up under the first letter of their root or stem. To find the root or stem you need to cut off all verbal prefixes, if these are present. The first verb (-phuza 'drink') has no prefixes, so you can look it up directly. With the last verb (kushisa 'it is hot') you first need to cut off the indefinite concord ( $k u$ 'it'), and then look up the verb stem (-shisa 'be hot'). Refer to your Zulu textbook for the correct use and meaning of all verbal prefixes, as well as for the sound changes that take place when attaching prefixes to one another and to roots and stems. In this dictionary, the most important verbal prefixes are listed in Tables 4 to 6, but remember that those tables do not replace the need for you to study and know the grammar of Zulu!

Comments 3: Although the example used to illustrate the dictionary system is a real example (and as a matter of fact, is one of the examples under the lemma ngazo ${ }^{2}$ ), it was chosen for its 'easiness' and the fact that the syntax in Zulu runs parallel to the English syntax. Implicitly, the difference with a pure stem approach is well illustrated, as there each of the orthographic words would need to be looked up under respectively -phuza, -nzi, -zo(na), -nke, -khathi, etc. In some of the existing Zulu dictionaries, such as Doke and Vilakazi's Zulu-English Dictionary (19532) or Dent and Nyembezi's Scholar's Zulu Dictionary $\left(1995^{3}\right)$, some of these indeed need to be looked up under their roots and stems, others have nonetheless been lemmatized under their full words, and for still others both options have been lemmatized.

Although a dictionary is not a grammar, all the important verbal prefixes have nonetheless been tabulated in the mini-grammar, again with the caveat that the learners should still consider their textbooks as well.

From this example, you can see that nouns have been listed as full words in your dictionary, so you will look up amanzi 'water' under the letter A in the alphabet (and not under N, the first letter of the noun stem, -nzi). Even (frequently used) plural nouns have been listed in your dictionary, so you can look up izikhathi 'times' directly. This is a unique feature of this dictionary, which makes it very easy to use.

Comments 4: After having briefly introduced the procedure to look up verbs, the next word class given a first brief attention is nouns. While verbs could be said to have been lemmatized like in traditional dictionaries (with this difference that extensive tables of verbal prefixes are included in the mini-grammar), the inclusion of full noun prefixes attached to noun stems is a radical departure from tradition (and also the main aspect singled out for review in Prinsloo 2010).

Verbs and nouns as two different word classes are used to introduce the concept of a 'word class' next.

So far we have said that you need to look up verbs under the first letter of their roots or stems, and that you need to look up nouns under their full forms. Verbs and nouns are two different word classes, so you can see that it is important that you know which word class a certain word belongs to. There are many different word classes in Zulu, and you will need to know how to look up words in each type of word class. We will explain this in detail below.

In addition to a word class, you will also often see a number or even a pair of numbers following the word class in your dictionary. This is because nouns 
in Zulu are traditionally grouped in different pairs of noun classes - which have unique pairs of noun class prefixes - and many other words have to be 'in harmony' with those noun class prefixes. In the example sentence, 'at all times' is ngazo zonke izikhathi in Zulu. Because the class 8 plural noun izikhathi is used, the temporal adverb ngazo and the inclusive quantitative pronoun zonke also have class 8 forms. If the class 7 singular noun isikhathi 'time' had been used, then the phrase would become ngaso sonke isikhathi 'all the time', with all words now in class 7 forms. It is very important that you understand this need for harmony (the so-called 'concordial agreement system') in Zulu, because only then will you appreciate the reason for assigning both a word class and class numbers to words in your Zulu dictionary. The different concords that are prefixed to verbs also need to be in harmony with the classes of the nouns they refer to, which is why all tables with concords consist of many lines: one line for each class, and a different concord for each class. The numbering system itself has been agreed upon internationally, so it is good you learn and know it.

Comments 5: This paragraph summarizes the core of the Bantu concordial agreement system, which is linked to the classification of Bantu nouns in noun classes, and a Bantu-wide numbering system. Note how the concept is gently introduced, by referring (twice) to a need for harmony, before the proper linguistic description is used. From a lexicographic point of view, the need to indicate the word class for each lemma, and (where relevant) the need to also indicate the class number, is also explained. Needless to say, the indication of class numbers across the word classes is missing from all existing dictionaries for Zulu.

\subsection{Word classes}

Most of the words listed in your dictionary are nouns and verbs. Actually, as many as $45.3 \%$ of all the dictionary entries are nouns, and $15.5 \%$ are verbs. Unique to this dictionary is that certain locative forms derived from nouns have also been listed as headwords; they make up $12.4 \%$ of your dictionary.

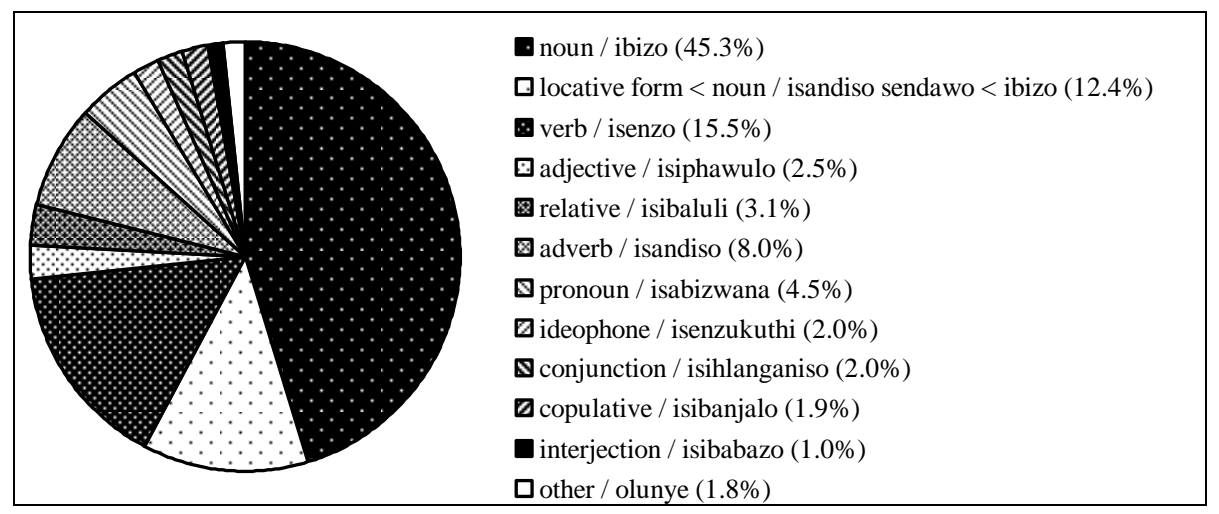

Figure 1: Distribution of the main Zulu word classes in your dictionary 
As the pie chart shown in Figure 1 indicates, these three groups of words (nouns, verbs, and locative forms derived from nouns) make up nearly threequarters of your dictionary. This does not mean that all the other word classes are less important - on the contrary. Many words in the other word classes are used much more frequently than some nouns and verbs. Words that 'accompany' nouns are typically adjectives and relatives; words that 'accompany' verbs are typically adverbs. To make well-formed sentences in Zulu, you also need to make use of pronouns, ideophones, conjunctions, copulatives, interjections, etc. We will now explain how you can look up words in each of these word classes.

Comments 6: With the concept of a word class introduced, it was now possible to extend the list of word classes to all the major ones in terms of number of members. In typical Zipfian style, some of the smaller word classes (in terms of members) actually contain the words used most often in Zulu (think for example of the class of the conjunctions). In the dictionary, actual word frequencies are indicated with a star rating following the lemma signs, an aspect explained in the Introduction to the OZSD. From the perspective of the dictionary user, the frequency breakdown shown in Figure 1 is most relevant, as it immediately tells that user how large each of the word classes is compared to the other word classes. The order shown in Figure 1 is also the order in which each of the word classes is given attention in the mini-grammar. That order combines both frequency (from most to least populous word class) and linguistic logic (e.g. bringing nouns together, or noun modifiers before verb modifiers, etc.). The coverage of each word class is henceforth fully driven by the relative frequencies seen in Figure 1. A word class with more members gets more attention than one with fewer ones, so on the whole this means that the sections become shorter and shorter as one proceeds through the different word classes in the mini-grammar. What is said about each word class is also fully driven by corpus facts, meaning that only what is most frequent in the corpus ends up being discussed. This is a radical departure from conventional grammatical descriptions, where one is interested in presenting full paradigms, irrespective of whether all items actually occur or not.

\subsection{Nouns}

Grammatically, a noun consists of a noun class prefix and a noun stem. The noun class prefix itself consists of a pre-prefix and a basic prefix. For example, the singular noun isikole 'school' consists of the pre-prefix $i-$, the basic prefix $-s i-$, and the noun stem -kole. To change a singular noun into a plural noun in Zulu, you need to change the form of the noun class prefix, here to izikole 'schools'. Nouns that have their singular in the isi-class and their plural in the $i z i$ - class belong to the class pair $7 / 8$.

In your dictionary, you need to look up nouns under the pre-prefix; thus under the letter I for isikole. Under isikole you will find a full treatment of this word, with frequency of use and grammatical information, a translation, and an example sentence. The full treatment is normally only found under the singular form (isikole), and not under the plural form (izikole). When a plural form is frequent, it has also been listed in your dictionary, but the only information you will find there is a cross-reference to the singular form. So it is important 
that you learn to recognize the full forms of nouns, with their pre-prefixes, and that you know how to change a plural noun into a singular noun. If you do not learn the system, you will spend more time thumbing through your dictionary, going from one entry to the next. The noun class system is shown in Table 1, which shows the main singular/plural noun pairs in your Zulu dictionary.

Table 1: Distribution of the singular and plural Zulu nouns in your dictionary

\begin{tabular}{|c|c|c|c|c|}
\hline $\begin{array}{l}\text { Class } \\
\text { (pair) }\end{array}$ & $\%$ & $\begin{array}{l}\text { Class } \\
\text { prefixes (1) }\end{array}$ & $\begin{array}{l}\text { Class } \\
\text { prefixes (2) }\end{array}$ & Notes \\
\hline $\begin{array}{l}1 / 2 \\
1 / 2\end{array}$ & $\begin{array}{l}4.6 \\
3.7\end{array}$ & $\begin{array}{l}\text { um-/aba- } \\
\text {.. }\end{array}$ & $\begin{array}{l}\text { umu-/aba- } \\
\text {.. }\end{array}$ & $\begin{array}{l}\text { (1) Polysyllabic stem I (2) Monosyllabic stem } \\
\text {.. }\end{array}$ \\
\hline $\begin{array}{l}1 a / 2 a \\
1 a / 2 a \\
1 a /-\end{array}$ & $\begin{array}{l}4.6 \\
2.1 \\
1.8\end{array}$ & $\begin{array}{l}\mathrm{u}-/ \mathrm{o}- \\
. \\
\mathrm{u}-\end{array}$ & & \\
\hline $\begin{array}{l}3 / 4 \\
3 / 4 \\
3 /-\end{array}$ & $\begin{array}{l}6.0 \\
3.7 \\
1.1\end{array}$ & $\begin{array}{l}\text { um-/imi- } \\
\text { um- }\end{array}$ & $\begin{array}{l}\text { umu-/imi- } \\
. . \\
\text { umu- }\end{array}$ & $\begin{array}{l}\text { (1) Polysyllabic stem I (2) Monosyllabic stem } \\
\text {.. } \\
. .\end{array}$ \\
\hline $\begin{array}{l}5 / 6 \\
5 / 6 \\
5 /-\end{array}$ & \begin{tabular}{r|}
11.4 \\
7.8 \\
1.1
\end{tabular} & $\begin{array}{l}\text { i-/ama- } \\
. . \\
\text { i- }\end{array}$ & $\begin{array}{l}\text { ili-/ama- } \\
\text {.. }\end{array}$ & $\begin{array}{l}\text { (2) Variant for some monosyllabic stems } \\
\text {.. }\end{array}$ \\
\hline 6 & 1.1 & ama- & & \\
\hline $\begin{array}{l}7 / 8 \\
7 / 8 \\
7 /-\end{array}$ & $\begin{array}{l}8.7 \\
7.0 \\
1.3\end{array}$ & $\begin{array}{l}\text { isi-/izi- } \\
. . \\
\text { isi- }\end{array}$ & $\begin{array}{l}\text { is-/iz- } \\
. . \\
\text { is- }\end{array}$ & $\begin{array}{l}\text { (1) Consonant-initial stem I (2) Vowel-initial stem } \\
\text {.. } \\
\text {.. }\end{array}$ \\
\hline $\begin{array}{l}9 / 10 \\
9 / 10 \\
9 /-\end{array}$ & $\begin{array}{l}9.2 \\
4.7 \\
2.9\end{array}$ & $\begin{array}{l}\text { iN-/iziN- } \\
\text { in- }\end{array}$ & $\begin{array}{l}\text { i-/izi- } \\
. \\
\text { i- }\end{array}$ & $\begin{array}{l}\text { (1) With } \mathrm{N}=\mathrm{m} \text { before } \mathrm{b}, \mathrm{p}, \mathrm{f} \text { and } \mathrm{v} \text {; else } \mathrm{N}=\mathrm{n} \\
\text { (2) When nasal-initial stem, or with some loanwords } \\
\text {.. }\end{array}$ \\
\hline $\begin{array}{l}11 / 10 \\
11 / 10\end{array}$ & $\begin{array}{l}2.7 \\
1.4\end{array}$ & $\begin{array}{l}\mathrm{u}-\mathrm{iziN}- \\
.\end{array}$ & $\begin{array}{l}\text { u-/izi- } \\
. .\end{array}$ & $\begin{array}{l}\text { (1) With } N=m \text { before } b, p \text {, } f \text { and } v \text {; else } N=n \\
\text { (2) When stem starts with } 1 \text { or } n\end{array}$ \\
\hline 11 & 1.6 & $\mathrm{u}-$ & ulw- & (1) Consonant-initial stem I (2) Vowel-initial stem \\
\hline 14 & 2.6 & ubu- & & + sound changes (=> uboya, utshani, utshwala) \\
\hline 15 & 4.4 & uku- & ukw- & (1) Consonant-initial stem I (2) Vowel-initial stem \\
\hline Other & 4.7 & & & \\
\hline & 100.0 & & & \\
\hline
\end{tabular}

Table 1 tells you that most nouns in your dictionary — as many as $11.4 \%$ belong to the singular class 5 , with their corresponding plural in class 6 . The notation $5 / 6$ is used for these nouns: the number in bold (5) refers to the class number of the noun you are looking at, the other number (6) to the corresponding (here a plural) class number. Examples are ikhanda 'head', ilanga 'day; sun', izwe 'country'. From Table 1 you can see that when you wish to look up the plural forms amakhanda 'heads', amalanga 'days; suns', amazwe 'countries', you can go directly to the letter I of your dictionary, to look up the singular forms. 
For some class pairs, there are two sets of class prefixes. For example, for $1 / 2$ one has both $u m-/ a b a-$ and $u m u-/ a b a-$. The pair $u m-/ a b a-$ is used with noun stems that have more than one syllable (which we call 'polysyllabic stems'). For instance, the noun stem of umfelokazi 'widow' / abafelokazi 'widows' has four syllables: -fe-lo-ka-zi. The pair $\boldsymbol{u m u}$-/aba-is used with noun stems that have only one syllable (which we call 'monosyllabic stems'). For instance, the noun stem of umukhwe 'father-in-law' / abakhwe 'fathers-in-law' has only one syllable -khwe. Therefore, if you want to look up a noun that starts with $a b a-$, Table 1 not only tells you that this is a plural noun, but also that the singular needs to be looked up under um-for a polysyllabic noun stem, and under $u m u$ - for a monosyllabic noun stem. For the class pair 3/4, one finds a similar situation: um-/imi- for polysyllabic stems, but umu-/imi- for monosyllabic stems.

Because nouns have been listed with their prefixes in your dictionary, you will not have problems looking up the alternative forms shown for the singular/plural pairs $5 / 6,7 / 8,9 / 10$, and $11 / 10$, nor for the alternative forms of class 11. As long as you remember to look up singular forms of nouns in full, you cannot go wrong. Similarly, 'difficult' class 14 nouns like uboya, utshani, or utshwala, can be looked up directly.

Comments 7: Table 1 is a quantified representation of the noun class system in Zulu, a first for this language. Noun classes are not considered in isolation, but are treated as genders, typically linking singular and plural members. In Column 1, dashes replace class numbers for one-class genders. Each number in bold, a notation first introduced in De Schryver (2001: 3-4), indicates the class of the member currently in focus. A noun class, as a member of a gender, is literally weighted (Column 2), and for each the various class prefixes are shown (Columns 3 and 4 , with explanations in Column 5). The order of those class prefixes (with Column 3 always more frequent than Column 4) is based on dictionary occurrences, unlike the presentation in traditional grammars, where the socalled full forms are always presented first (e.g. umu-/aba- before um-/aba-). Only what is actually found in the dictionary is mentioned in Table 1 (e.g. for gender 9/- one finds the prefix in- rather than $i \mathrm{~N}$-, simply because no nouns in gender $\mathbf{9}$ /- have been lemmatized that have the prefix im-, so there is no need to over-generalize). For linguists used to traditional Zulu grammars, a presentation like the one seen in Table 1 is undoubtedly a radical departure from more familiar presentations; for the user of the OZSD, however, this is simply in direct agreement with the word lemmatization used for nouns. ${ }^{10}$

Note, however, that when the pre-prefix of a noun is missing, as in lo muntu 'this person', you will first need to add the pre-prefix before looking up this noun under $\underline{u}$ muntu 'person'. Furthermore, various morphemes may be prefixed to a noun, and those need to be cut off. Thus, words like lomuntu 'of a person', ngumuntu 'she/he/it is a person', nomuntu 'with a person', njengomuntu 'like a person', ngomuntu 'about a person', okomuntu 'that of a person', ngingumuntu 'I am a person', wayengumuntu 'he was a person', etc. all need to be looked up under umuntu. Remember, therefore, that all nouns are listed under their pre-prefixes, which are either $a^{-}, i-, o_{-}$, or $u$ - Reformulated, all nouns have been listed under just four letters of the alphabet in your dictionary: A, I, O, or U. 
Comments 8: Although lemmatizing nouns with their full prefixes, thus as complete words carrying meaning, is also the most intuitive lemmatization approach, users should not be led to think that all nouns appear in this canonical form in written Zulu. This paragraph dispels this, and shows typical environments of words and morphemes preceding nouns, either written disjunctively or conjunctively. Cutting off the conjunctively written parts may be challenging for the beginner, restoring the pre-prefix, which is always a reflection of the vowel of the basic prefix, should be more manageable.

In your dictionary you will also find over a hundred so-called infinitive nouns. These are all nouns derived from verbs, and always take the noun class prefix of class 15 ( $u k u$ - or $u k w$-). These nouns have been chosen for a combination of two reasons: (i) they have new, independent meanings, and (ii) they are often used in Zulu. Examples are ukuhlolwa 'examination', ukulimala 'injury', or ukwenza 'action'. When the verb from which such an infinitive noun is derived has also been listed in your dictionary, you will see a cross-reference linking the noun to the verb, for instance ukwenza 'action' <-enza 'do, make, act; cause'. In general, all deverbatives (meaning all nouns which are derived from verbs) for which the verb is also listed in your dictionary, have been linked with that verb by means of a cross-reference. For example impilo 'life; health' < -phila 'live; be in good health'. Again, in this dictionary, you do not need to go to the alphabetic section PH (the first letters of the stem) in order to find the noun impilo; simply go directly to the first letter of the full noun, thus I.

Comments 9: The mini-grammar does not cover word formation processes, but cross-references in the dictionary do link deverbatives to their verb roots and stems whenever the latter have also been lemmatized. At the expense of fewer lemmas, cross-references in the other direction, thus from verb roots and stems to all the lemmas derived from those, could also have been considered. This was for example done in my Cilubà-Dutch Lexicon (De Schryver and Kabuta 1997) by means of what I termed '(frequency-based) tail slots' in my MA dissertation (De Schryver 1999: 53-54; cf. also De Schryver and Prinsloo 2001). Expecting Grade 4 to 9 learners to follow up on all cross-references away from a node, in addition to those from single spokes (deverbatives) to single nodes (verb roots or stems), was however considered too advanced for the OZSD.

When you do not find a certain noun under its singular form, this may be because the noun is infrequent and has thus not been listed in your dictionary. In some cases, however, the plural form was frequent enough to be listed, while the singular was not. In such cases, you will find a full treatment under the plural form. Examples include: amaphesenti 'percent; percentage', iziphumuzi 'punctuation marks', or izinhlobonhlobo 'different kinds'.

Lastly, note that not all possible singular/plural pairs have been listed in Table 1 (see the $4.7 \%$ 'Other'). Another combination is for example 9/6: ifilimu 'film, movie' / amafilimu 'films, movies', or inkosi 'chief, king' / amakhosi 'chiefs, kings'. Here too, your dictionary will show you the correct classes (9 and 6), as well as the exact forms (for example inkosi and amakhosi), so they should not be problematic to look up. 
Comments 10: In line with what was noted under Comments 6, what is mentioned in the minigrammar is restricted to what is both frequent and relevant for using the dictionary. Compared to Table 1, a staggering 19 further genders and combinations of genders are for example attested in the dictionary (nine of them hapaxes however), yet not knowing about those does not hamper successful dictionary use. Keeping them for a scientific article in which the noun class system of Zulu is revisited makes all the more sense. Likewise, there are also more (but infrequent) variant prefixes for some genders than the two columns of variants offered. For example, for class 11 the OZSD has one (and only one) lemma with the noun class prefix $u l u$-, namely uluthi 'stick; twig'.

\subsection{Locative forms derived from nouns}

Normally, a locative meaning can be 'added' to a noun from the class pairs $1 / 2$ or $1 \mathrm{a} / 2 \mathrm{a}$ by replacing the pre-prefix with the class 17 locative prefix $k u$ - (or the variant ko-). As such, umuntu 'person' becomes kumuntu 'to a person', or omalume 'uncles' becomes komalume 'to the uncles'. Especially with loanwords in the class pair 9/10, one may also find the variant kwi-. As such, inombolo 'number' becomes kwinombolo 'at the number'. Word forms like these are not hard to decode, and have therefore not been listed in your dictionary.

A second way to add a locative meaning to a noun is to replace the preprefix with $e$ - and to add the suffix -ini. As such, abantu 'people' becomes ebantwini 'to/from/among/... the people', or umthombo 'fountain, spring' becomes emthonjeni 'in/at/to/from/... the fountain/spring'. This approach may be used for nouns in all classes, except for those in class 11 or 14, where the pre-prefix is replaced with $o$-, again with the suffix -ini. As such uhlangothi 'side' becomes ohlangothini 'on/at/to/from/... the side', or ukhetho 'election' becomes okhethweni 'in the election'. Numerous sound changes are found when the suffix -ini is attached to nouns, as seen in the underlined parts in the examples here. It is mainly for this reason that all frequent locative forms that are derived from nouns using the so-called $e-/ o-\ldots-i n i$ 'locativisation strategy' have been listed directly into your dictionary. Grammatically, these locativised nouns have actually become 'locative adverbs'. To save space in the dictionary, only translations into English of the meanings are given for these locative adverbs, without any examples.

A second reason for listing these locative adverbs in your dictionary is that there are locativised nouns where the suffix -ini does not appear. The appearance or not of the suffix -ini is not predictable, which makes it useful to list the correct frequent forms in the dictionary. As such, all of the following forms for example appear without the suffix -ini: ebusika 'in/during/... winter' (<ubusika 'winter'), ekhaya 'at/from/... home' (< ikhaya 'home'), or olwandle 'in/on/to/ from /... the ocean/sea' (< ulwandle 'ocean, sea').

A third reason for listing these locative adverbs in your dictionary is that there are locativised nouns for which the frequency of the noun itself is extremely low (or may not even appear at all in our 8.5-million-word Zulu corpus). Examples include: emaphandleni 'in/to/from/... the rural areas', emsamo 'in/at/to/from/... the back of the hut', or esidlangalaleni 'in public; openly'. For 
all these examples the corresponding noun is not seen in the corpus, so it would be wrong to list such nouns in a dictionary that is corpus-driven and that focuses on frequently used words.

Lastly, as was the case for the nouns, locativised nouns may be preceded by one or more morphemes, which need to be cut off before they can be looked up in your dictionary.

Comments 11: This sub-section is entirely self-contained and provides an excellent argued example of the type of choices that had to be made with regard to the lemmatization or not of certain Zulu 'words'. Looking up nouns locativised by means of $k u$ - and its variants was considered manageable for the target user group, but locativisation by means of the $e-/ 0-\ldots-i n i$ strategy was not. For a linguistic account of the issues involved, see De Schryver and Gauton (2002).

\subsection{Verbs}

In this dictionary verbs need to be looked up under the first letter of their roots or stems. The same approach is followed in all dictionaries for Zulu. This is because each verb root or stem can combine with very many combinations of prefixes, and the ending of a verb also varies (it can be $-a,-e,-i,-i l e$, or -anga). Listing all these possibilities in a dictionary would not be practical, as one would need to list many dozens, sometimes hundreds of forms for each verb. This therefore means that you will need to learn to cut off all verbal prefixes and formatives from verbs (those listed in Tables 4 to 6 as well as all the others listed in your Zulu textbook) before you can look up the basic meaning of a verb.

Comments 12: Van Wyk (1995: 86-87) performed a quick, back-of-the-envelope calculation for Zulu, and claimed that "[t]he number of combinations possible for a suitable transitive verb stem is [...] $18 \times 19 \times 6 \times 2$," or thus 4104 . While the actual theoretical figure is many times higher (for one, Van Wyk did not take the variation in verb endings into account), corpus counts indicate that the number of those that are actually used is many times smaller. Disregarding the very rare uses, which would not have to feature in a word-based school dictionary anyway, the number of those that are used is still very high (many dozens to several hundred orthographic forms per verb root or stem, as stated in the mini-grammar), so a word-based approach to the lemmatization of verbs in a paper dictionary for Zulu is indeed not feasible. ${ }^{11}$ This thus means that we have come back to square one as far as the lemmatization of verbs in a paper dictionary for Zulu is concerned, in that the traditional approach is stuck too. The exercise was not futile, however, as the decision was arrived at following a study of large amounts of actual language use, rather than being based on linguistic extrapolations. The decision, in other words, can truly be defended.

A verb without any verbal prefixes and without any verbal extensions is known as a verb root. In your dictionary the final vowel $-a$ is always added to verb roots. Examples are -anga 'kiss', -linga 'try, attempt', and -thuma 'send'. $54.5 \%$ of all the verbs listed in your dictionary are verb roots. The other $45.5 \%$ of the verbs take one or more verbal extensions. When a verb takes a verbal extension, it is known as a verb stem. Verb stems are also shown together with the final vowel $-a$ in your dictionary. 
Comments 13: Some linguists may object to the terminology used here, and may prefer to talk about (formal or base) radicals and extended radicals rather than roots and stems respectively, and may prefer to view a stem as merely a root plus the verbal ending, with that root either a radical or extended radical (cf. e.g. Schadeberg 19923: 8).

In Table 2 the distribution of the verbal extensions in your dictionary, as well as the main combinations of verbal extensions, is shown.

Table 2: Distribution of Zulu verbs with verbal extensions in your dictionary

\begin{tabular}{|c|c|c|c|c|}
\hline Verbal extension & Form & Meaning & $\%$ & Examples \\
\hline passive & $-(\mathrm{i}) \mathrm{w}-$ & adds 'be', 'being' & 32.0 & -akhiwa, -khishwa, -shaywa \\
\hline applicative & -el- & adds 'for', 'on behalf of' & 16.6 & -buyela, -khulumela, -xoxela \\
\hline causative & -is- & adds 'cause to', 'help' & 13.6 & -balisa, -bhalisa, -qondisa \\
\hline neuter & $\begin{array}{l}\text {-ek- OR } \\
\text {-akal- }\end{array}$ & adds '-able/-ible' & 12.1 & -bhekeka, -bonakala, -tholakala \\
\hline reciprocal & -an- & adds 'each other' & 4.5 & -bambana, -bhekana, -xhumana \\
\hline applicative + passive & -elw- & adds 'be ... for $/$ by' & 4.5 & -balelwa, -banjelwa, -phelelwa \\
\hline causative + passive & -isw- & adds 'be ...' & 3.9 & -aziswa, -fundiswa, -setshenziswa \\
\hline causative + reciprocal & -isan- & adds '... each other' & 1.8 & -bonisana, -hambisana, -phikisana \\
\hline reciprocal + causative & -anis- & adds '... each other' & 1.2 & -ehlukanisa, -qondanisa, -xhumanisa \\
\hline perfective & -elel- & completes an action & 1.2 & -azelela, -bambelela, -phumelela \\
\hline intensive & -isis- & expresses intensity & 1.2 & -bhekisisa, -qondisisa, -zwisisa \\
\hline \multirow[t]{2}{*}{ Other } & & & 7.3 & \\
\hline & & & 100.0 & \\
\hline
\end{tabular}

Nearly one third (32.0\%) of all the verbal extensions simply add a passive meaning to a verb root, $16.6 \%$ add an applicative meaning, $13.6 \%$ a causative meaning, etc. Because all these verb stems (thus 'verbs with verbal extensions') have been listed directly into your dictionary, you do not need to memorize the various sound changes that apply when suffixing certain verbal extensions to verb roots. For example: -khipha + passive > -khishwa. Also, the exact meanings of the resulting verb stems are mentioned in the dictionary articles of those verb stems, with examples to support those meanings. It is a good idea now to look up each of the examples listed in Table 2, and to compare the dictionary information for each verb stem with that found under each verb root from which it is derived. (Note that a cross-reference always links a verb stem with its verb root, on the condition that that verb root is frequent enough to be listed in your dictionary.)

Comments 14: Although I said that verbs in the OZSD are lemmatized like in any other dictionary for Zulu, this is not entirely true in that this is only correct for verb roots (or for formal or base radicals if one prefers). Existing dictionaries for Zulu will not systematically lemmatize verb stems (or extended radicals). Doke and Vilakazi (19532), for example, do not include any verbs with passive extensions, and will furthermore normally only include those verbs with verbal extensions that have undergone some level of lexicalisation. In contrast, the OZSD systematically includes all frequent verb stems. 
you will see that translations and examples are only given for the combinations -bhekana na-, -hambisana na-, and -phikisana na-. Throughout your dictionary, all combinations are preceded by an empty diamond $(\diamond)$. Also, in your dictionary, when verbs combine with nouns to form new meanings, you will need to look up the noun and not the verb for those meanings. See for example the combinations with verbs listed under the nouns icala ${ }^{1}$, ithambo, or intwala.

Comments 16: Two of the examples mentioned are shown in (5) and (6) below:

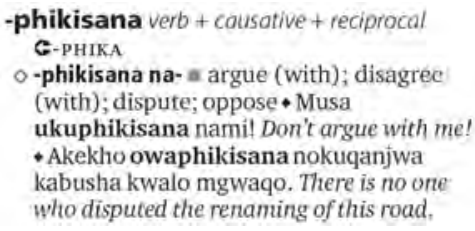

(6)

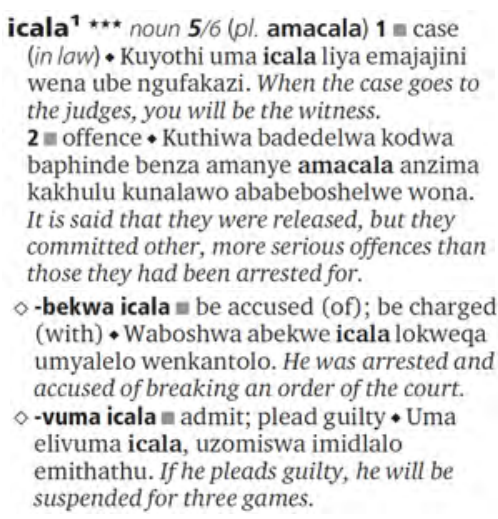

Thirdly, grammatical abbreviations may also be used in derivations and combinations. These are used to summarize a full list (known as a 'paradigm') of possibilities. For example, if you look up the verb stem -azelela, you will find the derivation $[S C+]$ ngazelele. Here SC stands for subject concord, and this notation means that any of the subject concords seen in Table 4 must precede -ngazelele in order to obtain the meaning.

Comments 17: The article for the verb stem -azelela is shown in (7) below:

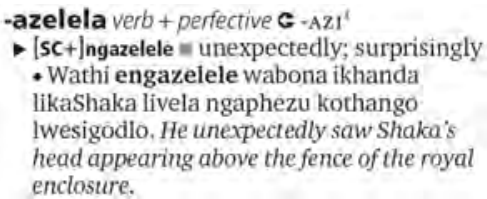

The various grammatical abbreviations used in your dictionary are listed in Table 3. 
Table 3: Grammatical abbreviations used in your dictionary

\begin{tabular}{|l|l|l|}
\hline Code & Meaning & For examples, see under \\
\hline$[\mathrm{DEM}+]$ & preceded by any demonstrative & lakho, lwethu, wethu \\
{$[\mathrm{NEG}+]$} & preceded by any negative & elangeni, isinqe, quthu \\
{$[\mathrm{PC}+]$} & any possessive concord prefixed to word & igolide, isihlanu, ngasese \\
{$[\mathrm{RC}+]$} & any relative concord prefixed to word & -banda, -mela, -phakama \\
{$[\mathrm{SC}+]$} & any subject concord prefixed to word & -azelela, ngokuphindwa, uzwelonke \\
{$[+\mathrm{LOC}]$} & followed by any locative & -balekela, - sebenzela, - shonela \\
\hline
\end{tabular}

Comments 18: As before, the dictionary user is expected to look up one or more of the examples given, in order to get acquainted with the dictionary system. As an illustration, one of the examples for the grammatical abbreviation [DEM+] is shown in (8) below:

(8) wethu ** possessive pronoun $1+1 p p /=$ our

- Ngisho nomqeqeshi wethu unethemba elikhulu ngalo mdlalo. Even our trainer

has a lot of faith in this game. $3+1 p$ plw our

- Kungumgomo wethu ukuphatha iziguli

ngesizotha nangesineke. It's our policy to

treat patients with dignity and care.

- $[\mathrm{DEM}+] \ldots$ wethu $=$ of ours $\bullet$ Kumele senzeni

nje nempela kulo mjondolo wethu? What

must we really do in this shack of ours?

Verbs are and will always be the most difficult part of speech to look up in a printed Zulu dictionary. This is so because a verb root or stem is normally 'hidden' in the middle of a much longer word. In order to help you recognize verb roots and stems, Table 5 lists the main verbal tenses and moods in Zulu. Table 5 has to be used together with Table 4 , as well as Table 6 . In a way, Tables 4,5 and 6 give you a short overview of the verbal grammar. Please read through this information slowly, and reread it often, until you memorize it.

Table 4: Verbal prefixes (SC and OC) to be cut off before looking up Zulu verbs, versus adjective prefix (AP) and relative concord (RC) to keep when looking up adjectives and relatives

\begin{tabular}{|c|c|c|c|c|c|c|c|c|c|c|}
\hline $\begin{array}{l}\text { Class } \\
\text { no. }\end{array}$ & $\begin{array}{l}\text { Class } \\
\text { prefix }\end{array}$ & $\begin{array}{r}+\mathrm{SC} \\
+\mathrm{C} \\
\end{array}$ & $\begin{array}{r}+\mathrm{SC} \\
+\mathrm{a} / \mathrm{e} \\
\end{array}$ & $\begin{array}{r}+\mathrm{SC} \\
+\mathrm{o} \\
\end{array}$ & $-\mathrm{SC}$ & $\sim \mathrm{SC}$ & $\S S C$ & OC & $\mathbf{A P}$ & $\mathrm{RC}$ \\
\hline $1 ; 1 a$ & $\mathbf{u m}(\mathbf{u})-; \mathbf{u}-$ & u- & w- & w- & ka- & e- & a- & $-\mathrm{m}(\mathrm{u})-$ & om $(u)-$ & o- \\
\hline $2 ; 2 a$ & aba-; o- & ba- & $b-$ & $b-$ & $=+\mathrm{SC}$ & be- & $=+S C$ & -ba- & aba- & aba- \\
\hline 3 & um(u)- & $\mathrm{u}-$ & w- & w- & wu- & $=+S C$ & $=+S C$ & -wu- & om $(u)-$ & o- \\
\hline 4 & imi- & i- & $y-$ & $y-$ & yi- & $=+S C$ & $=+S C$ & -yi- & emi- & e- \\
\hline 5 & i(li)- & li- & $1-$ & $1-$ & $=+S C$ & $=+\mathrm{SC}$ & $=+S C$ & - li- & eli- & eli- \\
\hline 6 & ama- & a- & $\varnothing$ & $\varnothing$ & wa- & e- & $=+S C$ & -wa- & ama- & a- \\
\hline 7 & is(i)- & si- & s- & s- & $=+\mathrm{SC}$ & $=+\mathrm{SC}$ & $=+S C$ & $-s i-$ & esi- & esi- \\
\hline 8 & iz(i)- & zi- & $z-$ & $z-$ & $=+\mathrm{SC}$ & $=+S C$ & $=+S C$ & $-z i-$ & eziN- & ezi- \\
\hline 9 & $\mathrm{i}(\mathrm{N})-$ & i- & $y^{-}$ & $y-$ & yi- & $=+S C$ & $=+S C$ & $-y i-$ & eN- & e- \\
\hline 10 & izi(N)- & $\mathrm{zi}-$ & $z^{-}$ & $z^{-}$ & $=+\mathrm{SC}$ & $=+\mathrm{SC}$ & $=+S C$ & $-z i-$ & eziN- & ezi- \\
\hline 11 & $\mathbf{u}(\mathbf{l u})-$ & lu- & lw- & $1-$ & $=+S C$ & $=+S C$ & $=+S C$ & -lu- & olu- & olu- \\
\hline 14 & ubu- & bu- & b- & $b-$ & $=+S C$ & $=+S C$ & $=+S C$ & -bu- & obu- & obu- \\
\hline
\end{tabular}




\begin{tabular}{|c|c|c|c|c|c|c|c|c|c|c|}
\hline 15 & uku- & ku- & kw- & k- & $=+S C$ & $=+S C$ & $=+S C$ & $-\mathrm{ku}-$ & oku- & oku- \\
\hline 17 & ku- & $\mathrm{ku}-$ & kw- & k- & $=+S C$ & $=+S C$ & $=+S C$ & $-\mathrm{ku}-$ & oku- & oku- \\
\hline $1 p$ sg & - & ngi- & ng- & ng- & $=+S C$ & $=+S C$ & $=+S C$ & -ngi- & engim(u)- & engi- \\
\hline $1 \mathrm{p} \mathrm{pl}$ & - & si- & s- & s- & $=+S C$ & $=+\mathrm{SC}$ & $=+\mathrm{SC}$ & $-s i-$ & esiba- & esi- \\
\hline $2 p s g$ & - & $\mathrm{u}-$ & w- & $w^{-}$ & $=+S C$ & $=+S C$ & $=+S C$ & $-k u-$ & om(u)- & O- \\
\hline 2p pl & - & ni- & n- & $n-$ & $=+S C$ & $=+S C$ & $=+\mathrm{SC}$ & -ni- & eniba- & eni- \\
\hline
\end{tabular}

Note that +SC depends on whether the initial letter of what follows is a consonant $(+C)$, an ' $a$ ' or ' $\mathrm{e}$ ' $(+a / e)$, or an 'o' $(+o)$.

Meanings of the abbreviations in Tables 4 and 5

\begin{tabular}{|l|l|l|l|}
\hline Abbreviation & Meaning & Abbreviation & Meaning \\
\hline $\mathrm{p}$ & person & $\mathrm{SC}$ & subject concord \\
$\mathrm{sg}$ & singular & $\mathrm{OC}$ & object concord \\
$\mathrm{pl}$ & plural & $\mathrm{AP}$ & adjective prefix \\
+ & positive & $\mathrm{RC}$ & relative concord \\
- & negative & $\mathrm{C}$ & consonant \\
$\varnothing$ & no concord & $\mathrm{V}$ & vowel \\
$\sim$ & situative; continuous & $\mathrm{N}$ & nasal \\
$\S$ & subjunctive & VERB & verb root or stem \\
\hline
\end{tabular}

Table 5: Verb formulas for the main Zulu tenses and moods (Note that an OC, when present, is always found immediately before the verb root or stem.)

\begin{tabular}{|c|c|c|c|c|}
\hline $\begin{array}{l}\text { Tenses and } \\
\text { Moods }\end{array}$ & + & & Formula & Examples \\
\hline Imperative & + & $\begin{array}{l}\text { sg } \\
\mathrm{pl}\end{array}$ & $\begin{array}{l}\text { VERB_a } \\
\text { VERB_a_ni }\end{array}$ & $\begin{array}{l}\text { bhala! 'write!', hamba! 'go!' } \\
\text { bhalani! 'write, all of you!', hambani! 'go, all of } \\
\text { you!' }\end{array}$ \\
\hline $\mathrm{VERB}=\mathrm{VC} \ldots$ & \{ & $\begin{array}{l}\text { sg } \\
\mathrm{pl}\end{array}$ & $\begin{array}{l}\text { y_VERB_a } \\
\text { y_VERB_a_ni }\end{array}$ & $\begin{array}{l}\text { yakha! 'construct!', yenza! 'do!' } \\
\text { yakhani! 'construct, all of you!', yenzani! 'do, all } \\
\text { of you!' }\end{array}$ \\
\hline \multirow[t]{3}{*}{$\mathrm{VERB}=\mathrm{C}(\mathrm{C})$} & \{ & $\begin{array}{l}\text { sg } \\
\text { pl }\end{array}$ & $\begin{array}{l}\text { yi_VERB_a } \\
\text { yi_VERB_a_ni }\end{array}$ & $\begin{array}{l}\text { yima! 'stand!', yidla! 'eat!' } \\
\text { yimani! 'stand, all of you!', yidlani! 'eat, all of } \\
\text { you!' }\end{array}$ \\
\hline & - & sg & musa uku_VERB_a & $\begin{array}{l}\text { musa ukudlala! 'don't play!', musa ukwesaba! } \\
\text { 'don't be afraid!' }\end{array}$ \\
\hline & & $\mathrm{pl}$ & musani uku_VERB_a & $\begin{array}{l}\text { musani ukuhleka! 'don't laugh, all of you!', musani } \\
\text { ukwethuswa! 'don't be surprised, all of you!' }\end{array}$ \\
\hline \multirow[t]{4}{*}{ Present } & + & long & +SC_ya_VERB_a & $\begin{array}{l}\text { uZodwa uyakhala 'Zodwa is crying', or 'Zodwa } \\
\text { cries' }\end{array}$ \\
\hline & & short & $\begin{array}{l}\text { +SC_ya_OC_VERB_a } \\
\text { +SC_VERB_a } \\
\text { [+object] }\end{array}$ & $\begin{array}{l}\text { ziyababulala 'they are destroying them' } \\
\text { igazi ligijima kalula 'the blood is running easily' }\end{array}$ \\
\hline & - & & $\begin{array}{l}+S C \_O C \_V E R B \_a \\
a_{-}-S C \_V E R B \_i\end{array}$ & $\begin{array}{l}\text { uma intombi ingithanda 'if a girl loves } \underline{m e}^{\prime} \\
\text { intsha yale mihla ayithandi ... 'the youth of today } \\
\text { do not like ...' }\end{array}$ \\
\hline & & & a_-SC_OC_VERB_i & $\begin{array}{l}\text { umfundisi akabaphi amaswidi 'the pastor doesn't } \\
\text { give them sweets' }\end{array}$ \\
\hline
\end{tabular}




\begin{tabular}{|c|c|c|c|}
\hline $\begin{array}{l}\text { Perfect / } \\
\text { Near past }\end{array}$ & $\begin{array}{l}+ \text { long } \\
\text { short }\end{array}$ & $\begin{array}{l}\text { +SC_VERB_ile } \\
\text { +SC_OC_VERB_ile } \\
\text { +SC_VERB_e } \\
\text { [+object] } \\
\text { +SC_OC_VERB_e } \\
\text { [+object] } \\
\text { a_-SC_VERB_anga } \\
\text { a_- } \\
\text { SC_OC_VERB_anga }\end{array}$ & $\begin{array}{l}\text { lowo mfana ubalekile 'that boy ran away' } \\
\text { ngikutshelile 'I've told you' } \\
\text { sizwe izindaba 'we heard the news' } \\
\text { uthisha ubavumele amaswidi 'the teacher allowed } \\
\text { them sweets' } \\
\text { angilalanga 'I could not sleep', or 'I didn't sleep' } \\
\text { wena awwyizwanga le ndaba? 'haven't you heard } \\
\text { this story?', wena awuyizwanga? 'you have not } \\
\text { heard it??' }\end{array}$ \\
\hline Stative & $\begin{array}{l}+ \\
- \\
\end{array}$ & $\begin{array}{l}\text { +SC_VERB_ile } \\
\text { a_-SC_VERB_ile }\end{array}$ & $\begin{array}{l}\text { kubalulekile 'it is important' } \\
\text { angilambile 'I am not hungry' }\end{array}$ \\
\hline $\begin{array}{l}\text { Remote } \\
\text { past }\end{array}$ & + & $\begin{array}{l}\text { +SC_a_VERB_a } \\
+ \text { +SC_a_OC_VERB_a } \\
\text { a_-SC_a_VERB_a } \\
\end{array}$ & $\begin{array}{l}\text { cishe ngafa! 'I nearly died!' } \\
\text { wangitshela 'you told me' } \\
\text { akahlala 'he didn't sit' }\end{array}$ \\
\hline Near future & + & $\begin{array}{l}\text { +SC_zo_VERB_a } \\
+ \text { +SC_zo_OC_VERB_a } \\
\text { a_-SC_zu_VERB_a } \\
\text { a_- } \\
\text { SC_zu_OC_VERB_a }\end{array}$ & $\begin{array}{l}\text { bazoqhubeka 'they will continue' } \\
\text { ngizomtshela ubaba 'I will tell father', ngizomtshela } \\
\text { 'I will tell him' } \\
\text { abazali abazukhokha 'the parents will not pay' } \\
\text { angizumbuza 'I will not ask her' }\end{array}$ \\
\hline $\begin{array}{l}\text { Remote } \\
\text { future }\end{array}$ & + & $\begin{array}{l}\text { +SC_yo_VERB_a } \\
\text { +SC_yo_OC_VERB_a } \\
\text { a_-SC_yu_VERB_a }\end{array}$ & $\begin{array}{l}\text { siyohlala 'we shall stay' } \\
\text { umkakho uyomthanda 'you will love your wife', } \\
\text { uyomthanda 'you will love her' } \\
\text { akuyubuya muntu 'no one will return' }\end{array}$ \\
\hline $\begin{array}{l}\text { Present } \\
\text { Situative / } \\
\text { Participial }\end{array}$ & + & $\begin{array}{l}\text { SC_VERB_a } \\
\sim S C \_n g a \_V E R B \_i\end{array}$ & $\begin{array}{l}\text { ngababona ababili beguqa 'I saw the two kneeling } \\
\text { down' } \\
\text { uma bengaphumeleli empilweni 'if they are not } \\
\text { succeeding in life' }\end{array}$ \\
\hline Subjunctive & + & $\begin{array}{l}\text { §SC_VERB_e } \\
\S S C \text { _nga_VERB_i } \\
\end{array}$ & $\begin{array}{l}\text { athathe amanzi aphuze 'then she takes water and } \\
\text { drinks' } \\
\text { intsha ingagcini 'the youth must not stop' }\end{array}$ \\
\hline $\begin{array}{l}\text { Past } \\
\text { continuous }\end{array}$ & + & be_ SC_VERB_a & bengihamba 'I was walking' \\
\hline $\begin{array}{l}\text { Future } \\
\text { continuous }\end{array}$ & + & $\begin{array}{l}\text { +SC_zo_be } \\
\text { SC_VERB_a }\end{array}$ & $\begin{array}{l}\text { uzobe egijima 'he will be running', amakwaya } \\
\text { azobe edlana imilala 'the choirs will be competing' }\end{array}$ \\
\hline
\end{tabular}

Table 6: A selection of other verbal formatives, to be cut off before looking up Zulu verbs

\begin{tabular}{|l|l|l|l|}
\hline Formative & Meaning & Translation & Place in formula \\
\hline -sa- & + progressive & 'still' & after SC \\
.. & - progressive & 'no longer' & .. \\
-nga- & + potential & 'can', 'may', 'could' & after SC \\
-nge- & - potential &.. &.. \\
-bo- & request & 'must' & after SC \\
-ka- & exclusive negative & 'not yet' & after SC \\
ka-, ma-, a- & hortatives & 'please', 'let' & before SC \\
-yo & relative & 'who', 'which', 'that' & after VERB \\
-ni & question & 'what?' & after VERB \\
\hline
\end{tabular}


Comments 19: The verb being the hardest word class to parse in Zulu, Table 5, together with the supporting Tables 4 and 6 , is truly the most important summary in the mini-grammar as a grammar, which should enable the dictionary users to decode (as well as encode) the language. These tables are undoubtedly overwhelming, a direct result of the highly complex nature of Zulu. No existing grammars of Zulu were consulted in building these tables. Rather, the Zulu corpus was queried and all frequent (and only the frequent) structures seen were described. The use of underscores to indicate morpheme boundaries in the verb formulas, as well as the decision to use a number of different labels for the subject concords ( $+\mathrm{SC}+\mathrm{C},+\mathrm{SC}+\mathrm{a} / \mathrm{e},+\mathrm{SC}+\mathrm{o},-\mathrm{SC}, \sim \mathrm{SC}, \S \mathrm{SC})$ all developed naturally during the effort to describe the corpus patterns seen. Rather than underscores, existing grammatical descriptions in Bantu at large also use dashes, hyphens and dots. Interestingly, for Zulu, the use of a well-defined set of subject concords was utilized to great effect in a series of studies on the Zulu verb published in the 1960s (Beuchat 1963, 1964, 1964a, 1966). In hindsight, the linguists who worked on Zulu half a century ago could very well have come up with overview tables such as Table 5. What they didn't have was evidence on frequency of occurrence. Also observe that all examples used in Table 5 have been selected from the OZSD, so are real examples. Parts in bold in the formulas and examples always refer to subjects, underlined parts to objects. While considerable efforts were put into the creation of this section of the mini-grammar, it should be remembered that this is not an exhaustive treatment of all aspects of the verb in Zulu, and as such far from complete. In places it is also decidedly too approximate. As a tool to support successful dictionary use, however, thus viewing the mini-grammar as a guide to use the dictionary, the level of detail is more or less the furthest one can go for a school dictionary.

The actual use of the material presented in the tables is illustrated next in the mini-grammar, followed by brief sections on auxiliary and copulative verbs.

For example, in the sentence Izidakamizwa ziyababulala abadlali abancane 'Drugs are destroying the young players', you should analyze the verb according to the formula +SC_ya_OC_VERB_a.

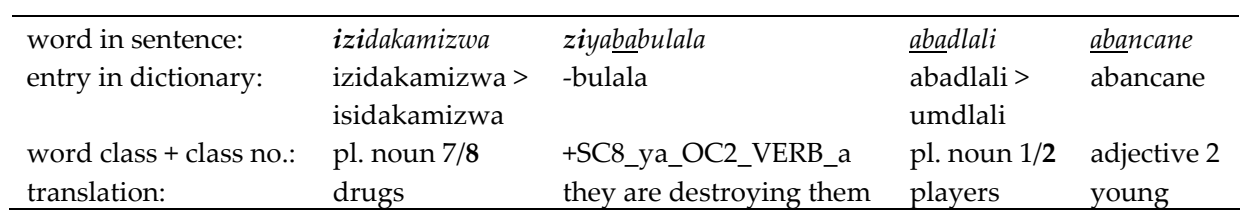

The -be in the formulas for the past and future continuous, seen in the last two blocks of Table 5, is actually the auxiliary verb stem -be. Please consult your Zulu textbook for the correct use of this auxiliary verb stem, as well as for the other frequently used auxiliary verb stem -se. Several usage examples may also be found in your dictionary, under the entries -be and -se. In addition to -be and -se, which are complex to use, there are also 50 other auxiliary verbs in your dictionary. Auxiliary verbs are typically used together with other verbs. For examples, see under -azi2, -buye or -ngahle in your dictionary. 
Comments 20: In (9) and (10) below, the complete articles for the auxiliary verbs -be and $-a z i^{2}$ as found in the OZSD are shown:

(9) -be *** auxiliary verb $1 \equiv$ was/were (in a

state); used to; had;

might/may/could/would have + Wabe

enezizathu zakhe ezamenza wesaba

ukubuya emini. He had his reasons to fear

returning in the afternoon. (Literally: $\mathrm{He}$

was in a state of being with reasons ...)

- Babe bephuma naye ngomnyango

ongemuva, They came out with him

through the back door. (Literally: They were

in a state of coming out ...) $\mathbf{2}=$ will $/$ shall

(be in a state); will/shall have

-Umqhudelwano uzokube

use-Stellenbosch. The competition will be in

Stellenbosch. $\bullet$ Kuzobe sekungokwesibili

evela kule nkantolo ngala macala, It will

be the second time that he appears in this

court in connection with these charges.

This auxiliary verb actually indicates a continuous

action or process, either in the remote past

(sense 1) or in the future (sense 2). The meaning

of this verb is not always reflected in English

translations. Note that "-be" can also be the

past tense of the copulative verb "-ba"

(10)

-azi ${ }^{2}$ *** auxiliory verb $\mathbf{C}-\mathrm{Az} 1^{\mathrm{x}}=$ be able to:

know how; can + Abafundi bangakwazi

ukuzicabangela okuqhubekayo. The

students should be able to think for

themselves progressively.

The copulative verb stem - $b a$ (with its past tense $-b e$ ) is also complex to use. For examples, see your dictionary under $-b a$, but only your Zulu textbook will teach you the correct use.

Comments 21: There is just one copulative verb stem in Zulu, namely -ba, which is why it is this verb that ends the section on verbs. In (11) below, the OZSD article for - $b a$ is shown:

(11) -ba ${ }^{* * *}$ copulative verb $=$ be; become

-Wahleka kwaze kwaba buhlung

izimbambo. He laughed until his ribs

became sore. + Mina bengithi kungaba

ngcono lokho sikwenze kusasa. I thought

that it would be better if we did that

tomorrow.

\subsection{Adjectives}

In Zulu, there are only a few adjective stems (such as -nye; -khulu; -bili; etc.). In your dictionary, 17 are covered, and for each of those adjective stems all the frequent full forms have been listed. 'Full form' here means the adjective stem together with the adjective prefix (AP in Table 4). As such, adjectives like omunye, ezinye; omkhulu, ezinkulu; ababili, ezimbili; etc. can all be looked up directly, thus under the first letter of the adjective prefix. 
Comments 22: For an exhaustive treatment of the lemmatization of adjectives in the OZSD, see De Schryver (2008a). In (12) and (13) below, two examples are given:

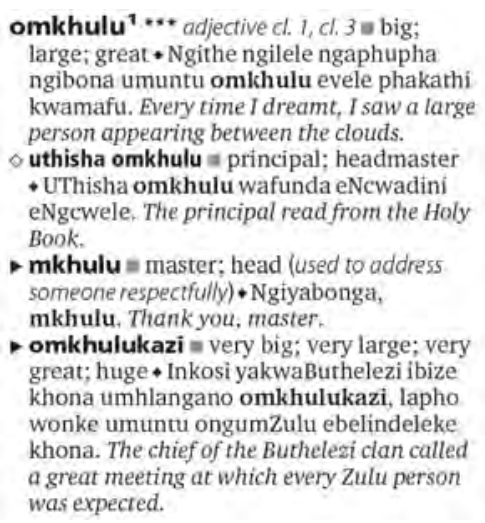

(For more on the suffix -kazi, as in omkhulukazi, see Gauton et al. 2004.)

(13) ezinkulu ** adjective cl. 8, cl. 10 big; large; great $\bullet$ Bayothenga ezitolo ezinkulu nasemakethe eku-Warwick Avenue eThekwini. They are going to shop in the large stores and the market in Warwick Avenue in Durban. + "Awu! Kanti yinina zinsizwa ezinkulu?" "My word! Is it you, big guys?"

\subsection{Relatives}

Compared to adjective stems, there are more relative stems in Zulu (e.g. -mhlophe; -mnandi; -thile). In your dictionary, 26 are covered, and for each of those relative stems all the frequent full forms have been listed. 'Full form' here means the relative stem together with the relative concord (RC in Table 4). As such, relatives like emhlophe, obumhlophe; emnandi, obumnandi; ethile, obuthile can all be looked up directly (under the first letter of the relative concord).

Comments 23: By and large, the lemmatization of relatives in the OZSD runs parallel to the way in which adjectives have been lemmatized. This is also implicit in the heading of Table 4, where both are contrasted to the way in which verbs have been lemmatized. In (14) and (15) below, two examples are given:

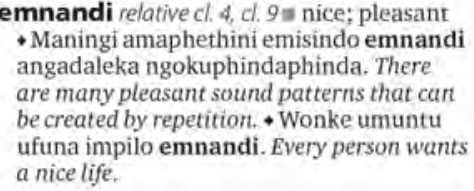

(15) obumnandi relative c. 14 mice; pleasant - Ngizolala ubuthongo obumnand namhlanje. I will have a nice sleep today. 


\subsection{Adverbs}

Zulu adverbs (for example impela, kangaka, or nakanjani) can be looked up directly.

Comments 24: Although the lemmatization of what Taljaard and Bosch (19932: 41) call 'true adverbs' should be plainly straightforward in any Zulu dictionary, some lexicographers manage to omit the adverb category altogether from their Zulu dictionaries. For example, the adverb impela 'really; actually; truly; indeed' - the 124 th most frequent lemma in the OZSD - has not been lemmatized in Mbatha's (2006) monolingual dictionary for Zulu. Instead, the infrequent noun ímpéla 'the real one' has been lemmatized, as Mbatha, following Nkabinde (1975), does not 'recognize' any word classes besides nouns, verbs, ideophones and interjections! Although not accepted by anyone else working on the Bantu languages, it is unfortunate that the Zulu National Lexicography Unit compiled their dictionary within this framework. ${ }^{12}$ The OZSD's dictionary entry for impela is shown in (16) below:

(16) impela ${ }^{\star * \star}$ adverb $=$ really; actually; truly;

indeed $\bullet$ U-Maurice wenze isimemezelo

ukuthi uyamthanda impela u-Minah.

Maurice announced that he truly loves

Minah.

Some adverbs have been subdivided into locative adverbs (for example kuwe, ngaphambi, phansi), adverbs of manner (for example kabi, ngokusemthethweni, njengenhlalayenza), temporal adverbs (for example kudala, manje, ngomhla), instrumental adverbs (for example ngabo ${ }^{1}$, ngathi, ngazo ${ }^{1}$ ), associative adverbs (for example nabo ${ }^{1}$, nathi, nazo), comparative adverbs (for example njengabo, njengathi, njengazo), and interrogative adverbs (for example kangakanani, kanjani, nini).

Comments 25: In addition to 'true adverbs', adverbs may also be derived from words in other word classes. Whenever the words from which such adverbs are derived have also been lemmatized as words in the OZSD, a cross-reference is included. One example each of the adverb subtypes included in the OZSD is shown in (17) to (23) below:

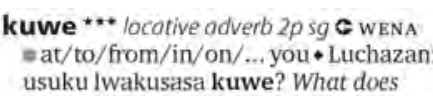

(18) ngokusemthethweni adverb of manner C EMTHETHWENI $=$ officially $\bullet$ Bonke

bafungiswe ngokusemthethweni yijaji.

uMnu. Vuka Tshabalala. All were sworn in

officially by the Judge, Mr Vuka Tshabatala.

(19) kudala ** temporal adverb $=$ long ago; in the past; in the old days • Ngakutshela kudala ukuthi angifuni ukushada. I told you a long time ago that I don't want to get married. 
(20) ngathi instrumental adverb lpp/ $\mathbf{c}$ тнімл

= about us • Ngesaba ukubatshela ngathi

sebeyoze bazibonele. I am afraid to tell

them about us; they will eventually find out

for themselves, $\equiv$ with us, Okwamanje

umqeqeshi usebenza kakhulu ngathi

ukuze sikwazi ukushaya amagoli amaningi.

At the moment the trainer is working very

hard with us, so that we can score many goals.

(21) nabo ${ }^{1 * * *}$ associative adverb $\boldsymbol{c}_{\mathbf{c}}$ воNА

$1=$ (cl. 2) with (them); to (them) $\bullet$ Hamba

nabo! Go with them! = also (they); (they)

too; even (they) • Bavuma nabo ngaleyo

ndledlana. They also agreed in that small

way. $\mathbf{2}=$ (cl. 14) also (it); (it) too; even (it)

- Njengazo zonke izinhlobo zesichasiso

ubumnini nabo bunezakhi ezimbili. Just

like all the other kinds of qualificative, the

possessive also has two formatives.

(22) njengazo comparative adverb ch. $8, c h .10$

C zonA $=$ (just) like (them) • Phela

ngiyazazi mina ukuthi sengimdala

njengazo nje izalukazi Baba. Of course, I

know that I am old now, just like the old

ladies, Father. * Angilitholanga ithuba

lokufunda njengazo zonke ezinye

izingane. I didn't get the opportunity to

study like all the other children.

(23) nini ***interrogotive adverb when? * Ufike nini lapha? When did you arrive here?

0 -noma nini $=$ whenever; anytime; any day

- Yinto ongangena esitolo uyithenge noma nini. It is something that you can go into a

store for any time and buy.

As a result of the word-based approach, numerous adverbs actually found their way into a dictionary for the very first time. From the above, all of the following have for example not been lemmatized in Doke and Vilakazi (19532): kuwe 'at/to/from/in/on/... you', ngokusemthethweni 'officially', njengenhlalayenza 'like every other day; as usual', ngomhla 'on (the day)', ngabo 'about (them, whom), etc.', ngathi 'about us, etc.', ngazo 'about (them, which), etc.', ..., nabo 'with (them), etc.', nathi 'with us', nazo 'with (them), etc.', ...

\subsection{Pronouns}

All Zulu pronouns can be looked up directly in your dictionary. They have been grouped together in seven different categories. Possessive pronouns are formed by combining a possessive concord (which refers to what is possessed) with a possessive stem (which refers to the possessor). In Table 7, you would therefore combine a PC with a Pstem to obtain forms like akhe, kwaso, or lwami. All these forms can be looked up directly, but you need to understand the numbers in the notation. For example: $6+1$ at akhe means that someone in class 1 'possesses' something in class $6 ; 15+7$ and $16+7$ at kwaso means that a noun in class 7 'possesses' a noun in class 15 or class $16 ; 11+1 \mathrm{p}$ sg at lwami means that I 
(the first person singular) 'possess' a noun from class 11. Please look at these examples in your dictionary so you become familiar with this system.

Comments 26: The lemmatization of possessive pronouns in the OZSD has been treated in De Schryver and Wilkes (2008). In (24) below, one example is given:

(24) kwaso * possessive pronoun 15+7 e its;

$$
\begin{aligned}
& \text { her/his }+ \text { Lesi saga sisazi } \\
& \text { ngokusetshenziswa kwaso. We know this } \\
& \text { proverb by its usage. } 16+7 \text { m of it; of } \\
& \text { her/him }+ \text { Wamisa phezu kwaso inqwaba } \\
& \text { enkulu yamatshe ekhona nanamuhla. On } \\
& \text { top of it he erected a great heap of stones } \\
& \text { that are there to this day. }
\end{aligned}
$$

\begin{tabular}{|c|c|c|c|c|c|c|c|c|c|c|c|}
\hline $\begin{array}{l}\text { Class } \\
\text { no. }\end{array}$ & $\begin{array}{l}\text { Class } \\
\text { prefix }\end{array}$ & PC & Pstem & \begin{tabular}{|l|} 
DEM \\
I
\end{tabular} & $\begin{array}{l}\text { DEM } \\
\text { II }\end{array}$ & $\begin{array}{l}\text { DEM } \\
\text { III }\end{array}$ & $\begin{array}{l}\text { Abs } \\
\text { Pron }\end{array}$ & $\begin{array}{l}\text { Incl Q } \\
\text { Pron }\end{array}$ & $\begin{array}{l}\text { Excl Q } \\
\text { Pron }\end{array}$ & $\begin{array}{l}\text { Incl Num } \\
\text { Pron "2" }\end{array}$ & $\begin{array}{l}\text { Incl Num } \\
\text { Pron "3" }\end{array}$ \\
\hline $\begin{array}{l}1 \\
1 \mathrm{a} \\
\end{array}$ & $\begin{array}{l}\text { um(u)- } \\
\mathbf{u}-\end{array}$ & $\begin{array}{l}\text { wa- } \\
\text { ka- }\end{array}$ & -khe & lo & lowo & lowaya & ye(na) & wonke & yedwa & - & - \\
\hline $\begin{array}{l}2 \\
2 a\end{array}$ & $\begin{array}{l}\text { aba- } \\
\text { o- }\end{array}$ & ba- & -bo & laba & labo & labaya & bo(na) & bonke & bodwa & bobabili & bobathathu \\
\hline 3 & um(u)- & wa- & -wo & lo & lowo & lowaya & wo(na) & wonke & wodwa & - & - \\
\hline 4 & ni- & ya- & -yo & le & leyo & leya & yo(na) & yonke & yodwa & yomibili & yomithathu \\
\hline 5 & i(li)- & la- & -10 & leli & lelo & leliya & lo(na) & lonke & lodwa & - & - \\
\hline 6 & ama- & a- & -wo & la & lawo & lawaya & wo(na) & (w)onke & (w)odwa & (w)omabili & (w)omathathu \\
\hline 7 & is(i)- & sa- & -so & lesi & leso & lesiya & so(na) & sonke & sodwa & - & - \\
\hline 8 & iz(i)- & za- & $-z o$ & lezi & lezo & leziya & zo(na) & zonke & zodwa & zo(zi)mbili & zo(zi)ntathu \\
\hline 9 & $\mathrm{i}(\mathrm{N})-$ & ya- & -yo & le & leyo & leya & yo(na) & yonke & yodwa & - & - \\
\hline 10 & izi(N)- & za- & $-z o$ & lezi & lezo & leziya & zo(na) & zonke & zodwa & zo(zi)mbili & zo(zi)ntathu \\
\hline 11 & u(lu)- & lwa- & -10 & lolu & lolo & loluya & lo(na) & lonke & lodwa & - & - \\
\hline 14 & ubu- & ba- & {$[-b o]$} & lobu & lobo & lobuya & bo(na) & bonke & bodwa & bobubili & [bobuthathu] \\
\hline 15 & uku- & kwa- & [-kho] & lokhu & lokho & lokhuya & kho(na) & konke & kodwa & kokubili & kokuthathu \\
\hline 16 & pha- & kwa- & [-kho] & lapha & lapho & laphaya & - & - & - & - & - \\
\hline 17 & ku- & - & - & lokhu & lokho & lokhuya & kho(na) & konke & kodwa & kokubili & kokuthathu \\
\hline $1 \mathrm{p} \mathrm{sg}$ & - & (wa-) & $-m i$ & - & - & - & mi(na) & wonke & ngedwa & - & - \\
\hline $1 \mathrm{p} \mathrm{pl}$ & - & (ba-) & -ithu & - & - & - & thi(na) & sonke & sodwa & sobabili & sobathathu \\
\hline $2 p s g$ & - & (wa-) & -kho & - & - & - & we(na) & wonke & wedwa & - & - \\
\hline $2 \mathrm{p} \mathrm{pl}$ & - & (ba-) & -inu & - & - & - & ni(na) & nonke & nodwa & nobabili & nobathathu \\
\hline
\end{tabular}

(I.e., the ukusetshenziswa 'usage' (cl. 15) of the isaga 'proverb' (cl. 7), and phezu 'on top' (cl. 16) of it, with 'it' something in cl. 7, to be inferred from the wider context.)

Table 7: Pronouns in Zulu (formatives and full words)

Meanings of the abbreviations and fonts in Table 7

\begin{tabular}{|l|l|ll|}
\hline Abbreviation & Meaning & Abbreviation & Meaning \\
\hline PC & possessive concord & Abs & absolute \\
Pstem & possessive stem & Pron & pronoun \\
DEM & demonstrative & Q & quantitative \\
I, II, III & position I, II, or III & Incl & inclusive \\
Italics & not in dictionary; frequency too low & Excl & exclusive \\
[Italics] & not in dictionary; not attested in corpus & Num & numeral \\
\hline
\end{tabular}


From the possessive pronouns one can also 'derive' relativised possessive pronouns. All the frequent ones have been listed directly into your dictionary; see for example awakhe (< akhe), eyabo (< yabo), or okwethu $(<k w e t h u)$. Also in this category are words like ezemfundo, ezemidlalo, or ezempilo.

Comments 27: In (25) and (26) below, two examples of relativised possessive pronouns are given:

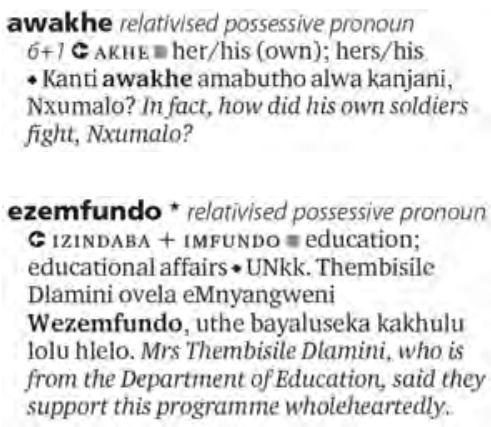

There are three types of demonstrative pronouns, positions I, II and III, depending on the 'distance' relative to the speaker ('here', 'there', and 'over there'). See Table 7 for all the main forms, and your dictionary for corresponding examples. When a demonstrative pronoun precedes a noun, the pre-prefix of the noun is dropped, and the demonstrative pronoun and the following noun are written as two words in the current orthography. The adverbial formatives $n g a-, n a-$, and njenga-, on the other hand, may be prefixed to the demonstrative pronouns, and thus written as one word. These formatives need to be cut off before looking up a demonstrative pronoun.

Comments 28: The OZSD being a corpus-driven dictionary, paradigms are not necessarily completed for the sake of completeness. In Table 7, Roman type is used to mark all forms frequent enough to be covered in the A-to-Z section of the OZSD. On the other hand, italics is used to mark those forms for which the frequency is too low to warrant inclusion in the A-to-Z section, while italics plus square brackets is used for forms not attested in the corpus at all, and thus most definitely absent from the A-to- $Z$ section. Frequent variants for position I, on the other hand, have been lemmatized.

In (27) to (30) below, one set is given for positions I, II and III for the class 4 and 9 demonstratives, as well as the corresponding variant for position I:

(27) le $\mathrm{e}^{\mathbf{x} \star * \star}$ demonstrative pronoun pos. I $1=(\mathrm{cl} .4)$ these (ones) - Le mithetho izoletha ezayo izinkinga. These laws will bring their own problems. 2 (cl. 9) this (one) $\bullet$ Iyiphi imoto edale le ngozi? Which car caused this accident?

(28) leyo ** demonstrative pronoun pos. II $\mathbf{C}_{\mathrm{LE}}$ 1 a (cl. 4) those (ones) $\bullet$ Leyo misebenzi yethu isemqoka njengayo yona leyo eminye. Those jobs of ours are as important as those other ones. 2 (cl. 9) that (one) - Kungabe yini leyo? What is that one? 
(29) leya demonstrative pronoun pos. III $\mathbf{C}_{\mathrm{LE}}$

$1=$ (cl. 4) those (ones) + Umuntu omunye

ubengathi sithandaza sibusisa leya

mikhuba ebigilwa yilaba bafana uyazi? You

know, another person might think we are

praying while blessing the tricks played by

those boys. $2=(\mathrm{cl}, 9)$ that (one) + Leya

ndawo iyaziwa ngomlando wayo. That

place is known for its history.

The person(s) or object(s) referred to is/are far

away in time or distance.

(30) Iena ${ }^{* * *}$ demonstrative pronoun pos. Ia $\in \mathrm{LE} \mathrm{E}^{t}$

$1=(\mathrm{cl}, 4)$ these (ones) \& Imikhonto lena

ibazwa ngendlela ethize ebalulekile kulesi

sizwe. These assegais are shaped in a very

special way in this nation. $\mathbf{2}=(\mathrm{cl} .9)$ this

(one) * Indatshana lena ingahlukaniswa

ibe yizingxenye eziyisithupha. This short

story can be divided into six parts.

This pronoun always follows the noun.

In Zulu, the absolute pronouns are used for emphasis or contrast. The full forms shown in Table 7 have been listed in your dictionary, together with important usage notes for each of them. Note that a large number of adverbs may be derived from absolute pronouns (for instance: bona > kubo, kubona, nabo, ngabo, njengabo).

Comments 29: In (31) below, one example of an absolute pronoun is given:

(31) sona ${ }^{* * *}$ absolute pronoun cl. 7 it (in

particular); she/he (in particular) • Sona

isizwe sakwaZulu siyobuswa ngubani? By

whom will the Zulu nation be governed?

-Yiso isipho sakho leso, ngiyakupha. That

is your gift; I am giving it to you.

The meaning of this pronoun is not always

directly visible in an English translation. When

"sona" is preceded by formatives such as "yi-",

"si-", "na-" or "ku-", the final emphasizing

syllable "-na" is usually deleted. See the second

example.

Finally, there are also three types of quantitative pronouns in Zulu, with which quantities are expressed. All the forms that have been listed in your dictionary are shown in the last four columns of Table 7. The inclusive quantitative pronouns (stem -nke) mean 'the whole' in the singular and 'all' in the plural. The exclusive quantitative pronouns (stem $-d w a$ ) mean 'alone' or 'only'. The inclusive numeral pronouns (only frequent stems -bili and -thathu) are used to refer to groups of items (here 'both' and 'all three' respectively). 
Comments 30: For an exhaustive treatment of the lemmatization of the three types of quantitative pronouns in the OZSD, see De Schryver (2008b). In (32) to (34) below, an example each is given:

(32) bonke *** inclusive quantitotive pronoum

$1=(\mathrm{cl}, 2)$ all $\bullet$ Bawethamela bonke abant umngewabo. All the people attended the funeral. $2=(\mathrm{cl} .14)$ all; the whole $\bullet$ Zilinde bonke ubusuku. They waited the whote night.

(33) odwa exclusive quantitative pronoun cl. 6 Compare woDwa $=$ alone; on their/its own -Wase ebona amaphoyisa asehlangana odwa endleleni. And then he saw the police assembling on their own in the street, $=$ only - Ukhuluma amanga odwa wena. You are only telling lies.

(34) sobabili inclusive numeral pronoun $7 p$ pl = both of us • Uthishanhloko ubefuna ukusibona sobabili emva kwesikole. The principal wanted to see both of us after school.

o [NEG + sobabili $=$ neither of us

\subsection{Ideophones}

Ideophones as a word class do not exist in English. In a language such as Zulu they are highly characteristic and their use signals good and beautiful Zulu. There are 100 ideophones in your dictionary. Examples are nya, phecelezi, and qho. Ideophones have been described as "marked words that vividly evoke sensations and perceptions". They are not problematic to look up, as no other morphemes are attached to them. However, they are very hard to translate. For that reason, only general paraphrases are given, between brackets and always preceded by 'of ...'. Often, several examples are shown, to illustrate the range of possibilities. Only when combined with verbs and nouns can rather fixed meanings be given. See for example the combinations under ngci, phaqa, or qakala.

Comments 31: For an exhaustive treatment of the lemmatization of ideophones in the OZSD, see De Schryver (2009). In (35) and (36) below, two examples are given:

(35) nya ** ideophone $=$ (of complete absence)

- Kwathula kwathi nya. It was completely silent. + Wayefuna ukukhohlwa nya yile ndaba kaNomusa. He wanted to forget this Nomusa affair completely. - Inyoka uyishaye wayibulala nya. He hit the snake and killed it altogether.

(36) $\quad$ ngci ideophone 1 = (of tightness, of density) - Ithi ngci intuthu. The smoke is very dense. - Abantu bacinana kuthi ngci. Akube kusaphefumuleka nakahle. There is a great crowd; it is no longer possible to breathe properly. $\mathbf{2}=($ of extreme action $)+$ Avuke umsindo uloku uthe ngci. Then he woke up while the noise continued to be overwhelming. 


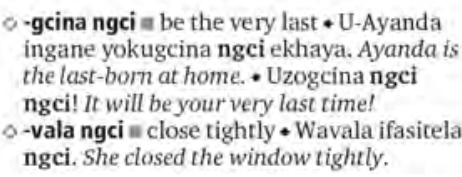

The description of ideophones as "marked words that vividly evoke sensations and perceptions" in the mini-grammar is taken from Dingemanse (2009). According to Blench:

Ideophones are abundant in natural and heightened speech, notably in Africa, but absent from typical example sentences, hence their failure to be treated adequately in typical grammars and dictionaries. They can be difficult to elicit since their existence is unpredictable and speakers have no natural 'hook' to recall them. Their elusive nature, in grammatical terms, has made them poor relations to other word classes and they have been little treated by the schools of grammar dominated by syntax [...] Our understanding of the role they play in natural language (as opposed to elicited examples) is still very preliminary.

- Blench (2009: 1)

As I pointed out in my own study of ideophones, compiling entries for ideophones in the OZSD "took an average three times longer than the compilation of entries in any other word class" (De Schryver 2009: 38). While the lemmatization proper of ideophones does not pose any problems (stable orthographic forms can simply be used as lemmas), I can reconfirm, with Blench, that the analysis and synthesis of large amounts of natural language data was simply paramount in order to make any sense at all of ideophones. Without the corpus used, in other words, it would simply not have been possible to treat ideophones adequately.

\subsection{Conjunctions}

Conjunctions in Zulu, as in English, introduce or link sentences. Examples are bese, ukuze, and nxa. Most conjunctions can be looked up directly, without the need to cut off additional prefixes. Conjunctions are very frequent. The most frequent word in Zulu is a conjunction (ukuthi), as well as the third-most frequent (uma), and the sixth-most frequent (ngoba).

Comments 32: In (37) below, the article for the conjunction $u k u t h i$ is shown:

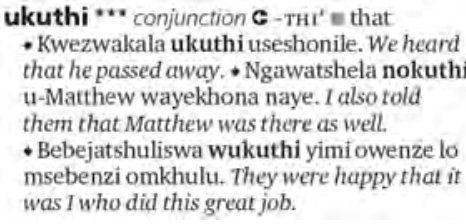

Ukuthi is one of the conjunctions to which morphemes may be prefixed. As is generally the approach in the OZSD, the top orthographic forms are illustrated in the examples. To that end, the orthographic forms cum linked corpus frequencies shown in (38) were available to the compilers. Although the frequency of $u k u t h i$ itself (131950) is many times higher than the frequency of all the other forms together $(5527+4552+\ldots)$, in order to illustrate the conjunctive potential for this lemma, the next few forms (here two) were also selected for illustrative purposes in (37). 
(38) ukuthi $\langle 131950>$, nokuthi $\langle 5527\rangle$, wukuthi $\langle 4552>$, yokuthi $\langle 1517\rangle$, ngukuthi $\langle 774>$, wokuthi $\langle 738\rangle$, ukuth $\langle 465\rangle$, elokuthi $\langle 315\rangle$, kungukuthi $\langle 315\rangle$, yikuthi $\langle 210\rangle$, kuwukuthi $\langle 141\rangle$, kunokuthi $<131>$, kwazisukuthi $<90>$, nawukuthi $<62>$, kwakungukuthi $<44>$

\subsection{Copulatives}

Copulatives in Zulu are typically derived from words in other word classes. To derive them, the prefixes are changed, with the goal to add the meaning 'is/are ...'. Derived from the relative stem -mhlophe, for example, the frequent copulatives listed in your dictionary are imhlophe, umhlophe, and zimhlophe. From the relative stem -mnandi, the frequent copulatives amnandi, imnandi, kumnandi, and zimnandi are derived and listed. Derived from the enumerative stem -phi, your dictionary lists the following frequent copulatives: (y)imuphi, yibaphi, yimiphi, (y)iliphi, yimaphi, (y)isiphi, yiziphi, (y)iyiphi, yiluphi, and (y)ikuphi. And derived from the interrogative stem -phi, your dictionary lists the following frequent copulatives: uphi, baphi, i(ku)phi, liphi, aphi, siphi, ziphi, luphi, and (ku)kuphi. In each case, you can look up all these forms directly, as full words in the dictionary, where you will find precise grammatical information, including a mention of the class numbers, as well as specific examples.

Comments 33: No other dictionaries for Zulu lemmatize copulatives. The decision to consistently lemmatize words wherever possible in the OZSD, however, naturally led to their inclusion. In (39) below, an example is shown:

$$
\begin{aligned}
& \text { umhlophe copulative } 1 \text { =(cl. } 1 \text { ) (she/he) is } \\
& \text { white } \bullet \text { Mfowethu, uma ungibukisisa } \\
& \text { ungasho ukuthi ngimnyama, yena } \\
& \text { umlungu umhlophe ngempela? My } \\
& \text { brother, if you look carefully at me, would } \\
& \text { you really say that I am black and that the } \\
& \text { white man is white? } 2 \text { =(cl. 3) (it) is white } \\
& \text {-Umyeko wezinwele umhlophe wu } \\
& \text { ngubuhlalu. The hair of the diviner is } \\
& \text { sparkling white with beads. } 3 \text { = (2p sg) you } \\
& \text { are white } \bullet \text { Umuhle kunezihlabathi } \\
& \text { zolwandle / Umhlophe kunobisi } \\
& \text { lwezimazi zakwethu [imigqa emi-2 } \\
& \text { yenkondlo] You are prettier than the sands } \\
& \text { of the sea/ You are whiter than the milk of } \\
& \text { our cows [two lines of poetry] }
\end{aligned}
$$

\subsection{Interjections}

Interjections in Zulu, as in English, are words 'thrown in' to mark surprise, pleasure, amazement, disbelief, disappointment, (dis)approval, (dis)agreement, etc. Examples are awu, hhayi, and wo. All interjections can be looked up directly. 
Comments 34: In (40) below, an example of an interjection is shown:

(40) awu ** interjection C HAwU a my word!;

good heavens!; look!; hey!; wow!; oh!;

eish! (marks a surprise or disbelief)

- Waphinde washaya izandla wathi: "Awu

Awu! Awu! Usuyasazi impela isiZulu." She

clapped her hands again and said: "Wow!

Wow! Wow! You know Zulu very well." • Awu

bayahlupha impela! Eish, they are really

bothersome!

\subsection{Other word classes}

Smaller word classes include enumeratives (for example all frequent forms of -ni: muni, mini, lini, mani, sini, zini, yini, luni, buni, and kuni), locative demonstrative copulatives (for example for class 1, positions I, II and III: nangu, nango, and nanguya), possessives (see for example alo ${ }^{2}, b_{a l o}{ }^{1}, k_{w a l o}^{2}$, etc.), interrogatives (see for example $n a, n g a b e^{2}$, or yini ${ }^{2}$ ), so-called suffixes (for example jikelele, ndini, or yansondo), enclitics (see for example $b o,-k e^{1}$, or $n j e^{1}$ ), hortative markers (ake and make), and abbreviations (a.m. and p.m.).

Comments 35: In (41) to (48) below, an example for each of these word classes is shown:

(41) muni enumerative cl. 1, cl. 3 = what kind of?

- Muntu muni ongathandi ukusizwa? What

kind of person doesn't like to be helped?

- U-Vincent wenza msebenzi muni? What

kind of work does Vincert do?

(42) nangu ** locative demonstrative copulative

pos. I $\mathrm{Cl} .1 \mathrm{e}$ here (she/he) is $\bullet$ Nangu

umuntu eqeda imali yabantu. Here is the person who wasted the people's money.

This word can also be used as a demonstrative,

with the meaning "this", e.g. "nangu

umfowethu" ="this brother of mine/ours".

(43)

$$
\begin{aligned}
& \text { alo }{ }^{2} \text { possessive } \mathbf{C} \text { Lo } 16+1=\text { of/for this } \\
& \text { - Elinye lamathemba alo Marion Jones } \\
& \text { owawina izindondo ezinhlanu e-Sydney, } \\
& \text { e-Australia ... One of the hopes of this Marion } \\
& \text { Jones who won five medals in Sydney, } \\
& \text { Australia ... } 26+3=\text { of / for this } \\
& \text {-Amalungiselelo e-Nigeria alo mdlalo } \\
& \text { aphazanyiswe wukulimala kukakaputeni } \\
& \text { yayo. Nigeria's preparations for this game } \\
& \text { were interrupted by the injury of their } \\
& \text { captain. }
\end{aligned}
$$

(For the next three entries, no translation equivalents are available. Note how the function is described rather, starting with the formulaic "marks ...".)

(44) na ** interrogative $=$ (marks interrogative sentences) • Usaphila na? Are you fine?

- Kwenzenjani na khona? What happened there? - Ungizwa kahle na? Do you understand me? 
(45) ndini * suffix $=$ (marks sarcasm or contempt) - Ake uthule Ndondo ndini, akusiwe ophethe lo mhlangano. Please keep quiet, smart Ndondo, you are not in charge of this meeting. $\bullet$ Ziphukuphukundini, niyedeleta kanti. You stupid fools, you are rude after all.

Although "ndini" is a noun suffix, it is generally written separately.

(46) bo ${ }^{* \star *}$ enclitic $=$ (marks insistence or anger) -Yicala lani-ke leli osulenzile? Khuluma bo! Ubulale umuntu yini? What type of crime have you committed? Speak up! Did you kill the person or not? • Hhayi bo! No, dammit!

ake ${ }^{* * *}$ hortative marker $=$ will you (please) ... ; let... (please) (marks a polite request) - Ake uchaze isifundo esitholakala kule ndaba. Will you please explain the lesson found in this story? - Manje ake sibheke le misho sibone ukuthi izenzo zakhiwa kanjani. Now let's look at these sentences and see how the verbs are structured.

(48) a.m. abbreviation = a.m.; in the morning (any time between midnight and midday) + Inkonzo izoqala ngesikhathi sika-10:00 a.m. The church service will begin at 10:00 a.m.

Sehora le-10 ekuseni is the traditional way to express at ten in the morning.

\section{Discussion}

Despite the fact that this paper is now already twice as long as the average scientific paper, the analysis of the OZSD is not all-embracing. This could not have been otherwise, as about a thousand pages are needed to do so (cf. Section 2). It is hoped, however, that all the claims made in the OZSD's Introduction have now been sufficiently substantiated:

The Zulu mini-grammar teaches you where to find particular words in the Zulu to English side of this dictionary, and thus teaches you Zulu-specific dictionary skills. It is very important that you study this section, because the method used to list Zulu words in this dictionary is new and therefore unfamiliar, but certainly more user-friendly. The result is a new type of Zulu dictionary, for the following reasons. Complete meaningful words have been entered in this dictionary, rather than parts of words. The selection of Zulu headwords is thus unique to this dictionary. The modern class numbers are used for all headwords: for nouns, of course, but also for all other word classes (parts of speech) that need to be in harmony with the nouns they refer to. Informative cross-references not only link verb stems with verb roots, but also derived nouns with the verbs they are derived from. In addition to headwords selected for their high frequency, this dictionary also treats all frequent combinations and frequent derivations. Headwords, combinations and derivations are illustrated with authen- 
tic Zulu examples, taken from a large corpus of sentences that have actually been written or spoken before. A corpus consists of hundreds and hundreds of texts, containing millions of words, that have been taken from both the general language and from school textbooks. All core and current meanings have been listed, based on such corpus evidence.

- De Schryver (2010: xi), emphasis in bold as in original

The actual reception of the OZSD will ultimately be the litmus test for the claim that this dictionary is more user-friendly as a school dictionary than any other existing dictionary for Zulu. I had noticed (see e.g. De Schryver 2008a: 64) that the stem approach to the lemmatization of Zulu failed this particular target user group, so I set out to develop a daring word approach. In the process I also introduced the various other novelties marked in bold in the quote from the Introduction above - all of them used for the first time in Zulu lexicography. It is important to recall, however, that this new approach was specifically designed for young learners. Although I am indeed convinced that it is ideal for them, I by no means want to claim that I have solved all look-up problems for a highly conjunctive Bantu language such as Zulu. By lemmatizing all word classes except one as words, I basically bring the entire look-up problem back to recognizing and dealing with the one remaining word class, viz. verbs. Reformulated, in decoding Zulu, the one remaining orthographic word in a sentence after the easier ones will have been looked up, will be the verb. One thus also knows it must be a verb, at which point Tables 4 to 6 can be unleashed. The verb is also the only word class in the OZSD that is lemmatized with a preceding dash, indicating that something was cut off before reaching the lemma in the dictionary. ${ }^{13}$

Compared to stem lemmatization, word lemmatization is undoubtedly more repetitive, even though that repetition is tailored to each sense of each lemma anew. The information that is packed in a stem dictionary has been unpacked in a word dictionary. Some level of generalization is therefore missed, though one could argue that providing that is the task of a grammar, not a dictionary. Up to a point, the mini-grammar restores this, and repacks. But the mini-grammar is not complete: a section on the morphophonological (sound) changes, for example, could have been added had there been space for it. What word lemmatization does do is to put the lexicon centre-stage, with the intricacies of each word dealt with in detail. The lexicon is seen as the pivot in mastering a language, not the grammar. Grammar can be built around the lexicon. This is quite a reversal of Bloomfield's (1933: 274) view of "[t]he lexicon [as] an appendix of the grammar, a list of basic irregularities". Being able to approach Zulu words rather than Zulu roots and stems is a direct result of the corpus revolution. So are most other microstructural innovations, chief among those the authentic examples to illustrate the synthesised analysis.

Abandoning generalizations, in combination with the extra information categories offered in the OZSD, also means that the focus shifts from quantity to quality. Rather than offering 30000 lemmas on about 920 pages as in Doke and Vilakazi's Zulu-English Dictionary (19532), or 13600 lemmas on about 220 
pages as in Dent and Nyembezi's Scholar's Zulu Dictionary (1995³), the OZSD offers 5000 lemmas on about 270 pages. ${ }^{14}$ The OZSD does fill a gap in the market, however, both in terms of its user-friendly access structure, and in terms of its coverage. Microstructurally, grammar was in effect brought into each dictionary article, systematic exemplification is a first for Zulu, and of course the lexicon was brought in line with current usage: meaning shifts resulted in new meanings which are now recorded, and hundreds of 'new' words were added to the macrostructure.

This paper comes after the lemmatization of some Zulu word classes have already been treated in the literature, and it is hoped that it can serve as a launching pad for all the remaining ones. For those treated before (possessive pronouns, adjectives, quantitative pronouns, and ideophones) comparing the tiny summaries presented in the mini-grammar (respectively Sections 3.9, 3.6, 3.9 , and 3.10 above) gives an idea of how a scientific description may be presented to the dictionary user. Conversely, the summaries for the other word classes give an idea of what the scientific descriptions will conclude. Concluding is one level, going through the details another, and performing the actual corpus analysis - in order to first synthesize the facts to then compile the dictionary articles themselves - is yet another, far more complex, level. In order for a thriving Bantu metalexicography to develop, more dictionaries will have to be compiled for these languages, so that more dictionary compilers will be able to share their experiences. As such, the present contribution is but one such attempt, hopefully one that will stimulate debate.

\section{Endnotes}

1. A workbook to accompany the Zulu dictionary is being planned as well.

2. While compiling the Northern Sotho dictionary took slightly over two and a half years, for the Zulu one nearly four years were required. From a lexicographic point of view, a conjunctively-written language such as Zulu is indeed much more complex to handle than a disjunctively-written one such as Northern Sotho.

3. With GET the general education and training band. Grades 10 to 12 (the last three years of secondary education) are known as FET, the further education and training band.

4. Together, the two A-to-Z sections and all extra-matter texts add up to 640 pages, or thus in the book-binding jargon, twenty 32-page signatures $(20 \times 32=640)$. Although tweaking the different sections, as well as the contents of those sections, until such a round multiple is reached is an important aspect of finalising an actual dictionary for the trade, this aspect will not be covered here.

5. Sincere thanks are due to A. Wilkes and D. Gowlett for their critical evaluation of the minigrammar, and to M. Hall for making sure the English of the mini-grammar is on the level of the intended target user group.

6. Verb lemmas, even as roots or stems, are actually also orthographic words, but only in their imperative forms. As such, one could say that the OZSD managed to lemmatize all Zulu words as words. However, given verbs rarely occur in their imperative forms, it is more cor- 
rect to stick to the traditional terminology, and to admit that verbs are lemmatized as roots and stems.

7. For more information on the preparation of a tailored lemma-sign list for junior dictionary users, balancing a general and a customised sub-corpus, see De Schryver and Prinsloo (2003).

8. The contract to produce the OZSD was signed between Oxford University Press Southern Africa and TshwaneDJe HLT, makers of the dictionary production system TLex.

9. Ideally, one would also have known which Zulu textbooks the learners would be using, so as to avoid the possibility of a diverging terminology, but in the absence of that knowledge, the best that could be done was to define each term and to use it accordingly in the OZSD.

10. Considerable thought also went into the way to present the information shown in Table 1 . One adjudicator in particular, suggested using dedicated columns for mono- vs. polysyllabic stems, additional columns for vowel- vs. consonant-initial stems, and then another column for the remainder of the notes now in the last column. I feel that a single notes column, with numbered notes referring to the earlier columns, is sufficiently clear.

11. In an electronic environment, where space is not an issue, lemmatizing all frequent verb forms becomes a possibility, either with the help of unlimited human resources or computational techniques, but at that point other problems surface, such as the abandonment of important generalizations (cf. De Schryver 2008: 269-270).

12. For a brief analysis of Mbatha's (2006) dictionary, and its implications, see De Schryver and Wilkes (2008: 829-830).

13. There are only seven exceptions in the OZSD: the conjunctions -thi and -the (unique in that these two only can take verbal prefixes), the relative stems -mbumbulu, -thize, and -thizeni (as these three are always used in compounds), the relative / copulative -emqoka (the only such combined word class), and the enclitic -ke (always attached to another word, with dash).

14. Extrapolated lemma-sign counts for Doke and Vilakazi as well as Dent and Nyembezi are taken from De Schryver (2009: 52).

\section{References}

Bennett, P.R. 1986. Grammar in the Lexicon, Two Bantu Cases. Journal of African Languages and Linguistics 8(1): 1-30.

Benson, T.G. 1964. A Century of Bantu Lexicography. African Language Studies 5: 64-91.

Beuchat, P.-D. 1963. A Restatement of the Zulu Verb Conjugation. Part 1. African Studies 22(4): 137169.

Beuchat, P.-D. 1964. A Restatement of the Zulu Verb Conjugation. Part 2. African Studies 23(1): 35-49.

Beuchat, P.-D. 1964a. A Restatement of the Zulu Verb Conjugation. Part 3. African Studies 23(2): 67-87.

Beuchat, P.-D. 1966. The Perfect Tenses in Zulu. African Studies 25(2): 61-71.

Blench, R. 2009. The Sensory World; Ideophones in Africa and Elsewhere. Draft circulated for comment; 5 October 2009 [online]. http://www.rogerblench.info/Language\%20data/Africa/General/ Blench\%20African\%20Ideophones.pdf

Bloomfield, L. 1933. Language. New York: Henry Holt \& Co.

Dent, G.R. and C.L.S. Nyembezi. $1995^{3}$ [19882, 1969]. Scholar's Zulu Dictionary. Pietermaritzburg: Shuter \& Shooter. 
De Schryver, G.-M. 1999. Bantu Lexicography and the Concept of Simultaneous Feedback, Some Preliminary Observations on the Introduction of a New Methodology for the Compilation of Dictionaries with Special Reference to a Bilingual Learner's Dictionary Cilubà-Dutch. Unpublished MA Dissertation. Ghent: Ghent University.

De Schryver, G.-M. 2001. Pukuntšuthaloši ya Sesotho sa Leboa 1.0 (PyaSsaL's First Parallel Dictionary). Pretoria: (SF) ${ }^{2}$ Press.

De Schryver, G.-M. 2004. Concepts and Tools for Lexicography in the Electronic Age - A Case Study of Dictionary Compilation in South Africa. Unpublished PhD Thesis. Ghent: Ghent University.

De Schryver, G.-M. 2006. Compiling Modern Bilingual Dictionaries for Bantu Languages: Case Studies for Northern Sotho and Zulu. Corino, E., C. Marello and C. Onesti (Eds.). 2006. Atti del XII Congresso Internazionale di Lessicografia, Torino, 6-9 settembre 2006 / Proceedings XII Euralex International Congress, Torino, Italia, September 6th-9th, 2006: 515-525. Alessandria: Edizioni dell'Orso.

De Schryver, G.-M. 2007. Oxford Bilingual School Dictionary: Northern Sotho and English / Pukuntšu ya Polelopedi ya Sekolo: Sesotho sa Leboa le Seisimane. E gatišitšwe ke Oxford. Cape Town: Oxford University Press Southern Africa.

De Schryver, G.-M. 2008. Why Does Africa Need Sinclair? International Journal of Lexicography 21(3): 267-291.

De Schryver, G.-M. 2008a. A New Way to Lemmatize Adjectives in a User-friendly Zulu-English Dictionary. Lexikos 18: 63-91.

De Schryver, G.-M. 2008b. The Lexicographic Treatment of Quantitative Pronouns in Zulu. Lexikos 18: 92-105.

De Schryver, G.-M. 2009. The Lexicographic Treatment of Ideophones in Zulu. Lexikos 19: 34-54.

De Schryver, G.-M. 2010. Oxford Bilingual School Dictionary: Zulu and English / Isichazamazwi Sesikole Esinezilimi Ezimbili: IsiZulu NesiNgisi, Esishicilelwe abakwa-Oxford. Cape Town: Oxford University Press Southern Africa.

De Schryver, G.-M. and R. Gauton. 2002. The Zulu Locative Prefix ku- Revisited: A Corpus-based Approach. Southern African Linguistics and Applied Language Studies 20(4): 201-220.

De Schryver, G.-M. and N.S. Kabuta. 1997. Lexicon Cilubà-Nederlands, Een circa 2500-lemma's-tellend strikt alfabetisch geordend vertalend aanleerderslexicon met decodeer-functie ten behoeve van studenten Afrikaanse Talen E Culturen aan de Universiteit Gent. Recall Linguistics Series 1. Ghent: Recall.

De Schryver, G.-M. and D.J. Prinsloo. 2001. Towards a Sound Lemmatisation Strategy for the Bantu Verb through the Use of Frequency-based Tail Slots - with Special Reference to Cilubà, Sepedi and Kiswahili. Mdee, J.S. and H.J.M. Mwansoko (Eds.). 2001. Makala ya kongamano la kimataifa Kiswahili 2000. Proceedings: 216-242, 372. Dar es Salaam: TUKI, Chuo Kikuu cha Dar es Salaam.

De Schryver, G.-M. and D.J. Prinsloo. 2003. Compiling a Lemma-sign List for a Specific Target User Group: The Junior Dictionary as a Case in Point. Dictionaries: Journal of The Dictionary Society of North America 24: 28-58.

De Schryver, G.-M. and A. Wilkes. 2008. User-friendly Dictionaries for Zulu: An Exercise in Complexicography. Bernal, E. and J. DeCesaris (Eds.). 2008. Proceedings of the XIII EURALEX International Congress, Barcelona, 15-19 July 2008: 827-836. Sèrie Activitats 20. Barcelona: Institut Universitari de Lingüística Aplicada, Universitat Pompeu Fabra. 
Dingemanse, M. 2009. How to Do Things with Ideophones: Observations on the Use of Vivid Sensory Language in Siwu. Presentation at the SOAS Research Seminar, June 3. London: The School of Oriental and African Studies.

Doke, C.M. and B.W. Vilakazi. 19532 [1948]. Zulu-English Dictionary. Johannesburg: Witwatersrand University Press.

Gauton, R., G.-M. de Schryver and L. Mohlala. 2004. A Corpus-based Investigation of the Zulu Nominal Suffix -kazi: A Preliminary Study. Akinlabi, A. and O. Adesola (Eds.). 2004. Proceedings of the 4th World Congress of African Linguistics, New Brunswick 2003: 373-380. Cologne: Rüdiger Köppe Verlag.

Mbatha, M.O. 2006. Isichazamazwi sesiZulu. Pietermaritzburg: New Dawn Publishers.

Nabirye, M. 2008. Compilation of the Monolingual Lusoga Dictionary. Unpublished MA Dissertation. Kampala: Makerere University.

Nabirye, M. 2009. Eiwanika ly'Olusoga. Eiwanika ly'aboogezi b'Olusoga n'abo abenda okwega Olusoga [A Dictionary of Lusoga. For Speakers of Lusoga, and for Those Who Would Like to Learn Lusoga]. Kampala: Menha Publishers.

Nabirye, M. 2009a. Compiling the First Monolingual Lusoga Dictionary. Lexikos 19: 177-196.

Nabirye, M. 2009b. Dictionary Compilation for Mother-tongue Speakers of Bantu Languages. Zhu, R. (Ed.). 2009. Proceedings of the International Seminar on Kangxi Dictionary E Lexicology: 597607. Beijing: Beijing Normal University.

Nkabinde, A.C. 1975. A Revision of the Word Categories in Zulu. Unpublished PhD Thesis. Pretoria: UNISA.

Prinsloo, D.J. 2009. Current Lexicography Practice in Bantu with Special Reference to the Oxford Northern Sotho School Dictionary. International Journal of Lexicography 22(2): 151-178.

Prinsloo, D.J. 2010. Review: The Oxford Bilingual School Dictionary: Zulu and English. Lexikos 20: 760766.

Prinsloo, D.J. and G.-M. de Schryver. 2002. Towards an 11 x 11 Array for the Degree of Conjunctivism / Disjunctivism of the South African Languages. Nordic Journal of African Studies 11(2): 249-265.

Schadeberg, T.C. $1992^{3}$ [1984²]. A Sketch of Swahili Morphology. Grammatical Analyses of African Languages 2. Cologne: Rüdiger Köppe Verlag.

Snoxall, R.A. 1965. Some Problems and Principles of Lexicography in Luganda. African Language Studies 6: 27-31.

Taljaard, P.C. and S.E. Bosch. $1993^{2}$ [1988]. Handbook of isiZulu. Pretoria: J.L. van Schaik.

Taljard, E., G.-M. de Schryver, M. Mogodi and D. Paizee. 2008. Oxford Bilingual School Dictionary Workbook: Northern Sotho and English / Puku ya Mešomo: Pukuntšu ya Polelopedi ya Sekolo: Sesotho sa Leboa le Seisimane. E gatišitšwe ke Oxford. Cape Town: Oxford University Press Southern Africa.

TLex (formerly TshwaneLex). 2010. TshwaneLex Dictionary Production System [online]. http:// tshwanedje.com/tshwanelex/

Van Wyk, E.B. 1995. Linguistic Assumptions and Lexicographical Traditions in the African Languages. Lexikos 5: 82-96. 